\title{
Immunotherapy targets in pediatric cancer
}

\author{
Rimas J. Orentas*, Daniel W. Lee and Crystal Mackall * \\ Pediatric Oncology Branch, National Cancer Institute, National Institutes of Health, Bethesda, MD, USA
}

\section{Edited by:}

Stephen Lessnick, University of Utah, USA

\section{Reviewed by:}

Carola Arndt, Mayo Clinic, USA

Nikolaus S. Trede, University of Utah, USA

\section{${ }^{*}$ Correspondence:}

Rimas J. Orentas and Crystal Mackall, Pediatric Oncology Branch, National Cancer Institute, National Institutes of Health, 10 Center Drive, 1W-3750, Bethesda, MD 20892, USA. e-mail: rimas.orentas@nih.gov; mackallc@mail.nih.gov
Immunotherapy for cancer has shown increasing success and there is ample evidence to expect that progress gleaned in immune targeting of adult cancers can be translated to pediatric oncology. This manuscript reviews principles that guide selection of targets for immunotherapy of cancer, emphasizing the similarities and distinctions between oncogene-inhibition targets and immune targets. It follows with a detailed review of molecules expressed by pediatric tumors that are already under study as immune targets or are good candidates for future studies of immune targeting. Distinctions are made between cell surface antigens that can be targeted in an MHC independent manner using antibodies, antibody derivatives, or chimeric antigen receptors versus intracellular antigens which must be targeted with $\mathrm{MHC}$ restricted T cell therapies. Among the most advanced immune targets for childhood cancer are CD19 and CD22 on hematologic malignancies, GD2 on solid tumors, and NY-ESO-1 expressed by a majority of synovial sarcomas, but several other molecules reviewed here also have properties which suggest that they too could serve as effective targets for immunotherapy of childhood cancer.

Keywords: immunotherapy, tumor antigens, pediatric cancer, adoptive immunotherapy, chimeric antigen receptor, antibody therapy, tumor immunity

\section{PRINCIPLES GUIDING SELECTION OF TARGETS FOR IMMUNOTHERAPY OF CANCER}

Improved outcomes for childhood cancer rests upon the development of new, targeted therapies to kill tumor cells. Much work has focused on targeting oncogenes mediating growth pathways to which the tumor has become "addicted" (Diehl et al., 2007; Sharma and Settleman, 2007; Weinstein and Joe, 2008). This strategy has yielded some impressive results, including the development of ABL inhibitors for chronic myeloid leukemia (Cortes et al., 2011), KIT inhibitors for gastrointestinal stromal tumor, and BRAF inhibitors for melanoma (Dhomen and Marais, 2009; Ribas and Flaherty, 2011). However, not uncommonly, oncogene inhibitors fail to mediate significant antitumor effects due to redundant growth/survival pathways that bypass the targeted pathway (e.g., FLT3 inhibitors in acute myeloid leukemia, EGF inhibitors in lung cancer; Diehl et al., 2007; Christoffersen et al., 2009; Normanno et al., 2009; Siena et al., 2009). For this reason, oncogene-inhibition has not yet assumed a major role in the treatment of pediatric cancers.

An alternative paradigm for targeted cancer therapy utilizes immune based therapies where the principles underlying target selection differ in some ways from those driving selection of oncogene-inhibition targets (Cheever et al., 2009). Most notably, while oncogene-inhibition targets must mediate non-redundant growth/survival pathways, immune targets need not play a significant role in the life or death of the cancer cell since they serve only to direct immune effectors to the tumor cell. Selection of antigen negative variants can occur when targeting non-essential molecules (Czerniecki et al., 2007; Sampson et al., 2010), but thus far this has not been the major factor limiting the effectiveness of immune based therapies (Smith, 2003). Thus, while it is desirable for immune targets to be involved in tumor growth/survival, this is not a requirement.

A second area whereby target selection for oncogene-inhibition differs from immunotherapy relates to the importance of tumorspecific mutations. Mutated genes are compelling targets for oncogene-inhibition since they implicate the target as a "driver" in oncogenesis, and mutated kinases can be specifically targeted with small molecules. For immune based targeting, mutated targets present both opportunities and challenges. Tumor-specific mutations are predicted to be more immunogenic than non-mutated molecules, since immune tolerance to somatically mutated molecules is not induced during normal development. Consistent with this, early encouraging results have been reported with a vaccine targeting EGFRvIII, a mutated EGFR in gliomas (Sampson et al., 2010). But, the corollary is that the number of epitopes generated by most mutations is small, and the likelihood that any one epitope will be immunogenic is also very small. Because most mutated molecules in cancer reside intracellularly and can only be recognized by $\mathrm{MHC}$ restricted $\mathrm{T}$ cell receptors, the epitopes that are "immunogenic" will be so only in the fraction of the population expressing the appropriate MHC allele. For example, the breakpoint regions of PAX3-FKHR (van den Broeke et al., 2006) and SYS-SSX2 (Worley et al., 2001) are predicted to be immunogenic in HLA-B $7^{+}$individuals, which comprise only approximately $15 \%$ of the population. Immune therapies that target one epitope present in only a small fraction of the population are difficult to standardize and translate into off-the-shelf therapies. Thus, very few tumor-specific mutations have been targeted successfully via immunotherapy.

Despite these challenges, the likelihood that immunogenic epitopes are present in any individual cancer increases with an 
increase in mutation frequency. Carcinomas are estimated to carry, on average, 7-10 unique, novel mutations capable of being recognized by the immune system (Segal et al., 2008). Such "tumor-specific" immunogenicity was directly demonstrated in early studies of carcinogen induced sarcomas wherein tumorspecific immunity in individual tumor bearing mice was not found in genetically identical littermates bearing tumors of the same histology, presumably due to the presence of unique tumor-specific mutations in individual tumors (Wortzel et al., 1983). This concept of "private antigens" provides rationale for patient-specific immunotherapies such as whole cell vaccines, and/or broad based immunomodulators such as anti-CTLA4 or anti-PD1, which can augment immunity to "personal epitopes" and result in meaningful antitumor effects across populations, albeit to different epitopes in different individuals (Peggs et al., 2006; Ascierto et al., 2010).

A third point to consider when selecting immune based targets relates to exclusivity of tumor expression. Tumor exclusivity is desirable but rare, and target expression on some normal tissues is not necessarily a barrier to immune based targeting. Many successful immune targets display some normal tissue expression, including cancer-testis antigens that are also expressed on testicular germ cells, prostate specific antigen, and prostate acid phosphatase expressed in normal prostatic tissue, gp100, and tyrosinase expressed by normal melanocytes, and CD19, CD20, and CD22 expressed by normal B-cells. Normal tissue expression does however carry the risk of on-target, off-tumor effects, as evidenced by vitiligo following immunotherapy for melanoma due to damage to normal melanocytes (Turk et al., 2002; Luiten et al., 2005; Gogas et al., 2006), and loss of normal B-cells when targeting B-cell antigens (Kochenderfer et al., 2010). High-level expression can also limit the effectiveness of immunotherapy by inducing immune tolerance or by competing with the tumor target. Moreover, even limited non-tumor expression on vital organs can lead to unacceptable toxicity. Thus, optimal immune based targets do not necessarily require tumor exclusivity, but should have limited normal tissue expression that does not include cells required for maintaining vital tissue or organ functions.

Working from these fundamental principles, this manuscript will discuss candidate targets for immune based therapies of childhood cancer, including cell surface antigens suitable for non-MHC restricted targeting as well as MHC restricted T cell targets.

\section{CELL SURFACE ANTIGENS: NON-MHC RESTRICTED IMMUNE TARGETS IN PEDIATRIC CANCER}

Immune based targeting of tumor cell surface molecules can utilize native antibodies, antibody-derived molecules linked to drugs, toxins, or radioactive isotopes, bi-specific antibodies that recruit effector immune cells (Baeuerle and Reinhardt, 2009), or T or NK cells genetically engineered to express a receptor that recognizes the antigen. Recently affinity-matured oligonucleotide structures, termed aptamers, have been used to target the tumor cell surface as well (Pastor et al., 2011). Regardless of the approach used, one compelling feature of targeting cell surface antigens in pediatric cancers is the lack of MHC restriction, which renders therapies applicable to all patients expressing the antigen on their tumor cells, regardless of MHC allele expression.

Historically, monoclonal antibodies, or their derivatives, could only passively target cell surface antigens, mediating antitumor effects only as long as the antibody was present. T cell based therapies, in contrast could mediate active immunotherapy, since they had the potential for in vivo expansion, long-term persistence, and immune memory. These advantages of $\mathrm{T}$ cell based therapies, however, were offset by limitations posed by MHC restriction, where any particular antigen could only be targeted in individuals with a particular MHC allele. The development of chimeric antigen receptors (CARs), which endow $\mathrm{T}$ cells with the reactivity of a monoclonal antibody, combines the benefits of $\mathrm{T}$ cell based therapy but with MHC independence (Figure 1). For these reasons, many are optimistic that CARs will ultimately prove to be effective, off-the-shelf reagents with broad applicability in cancer (Urba and Longo, 2011). The fact that academia can generate these therapies, without the large scale pharmaceutical investment required for small molecule oncogene inhibitors, further enhances the attractiveness of this approach for targeting rare cancers, such as those occurring in children. For a detailed discussion of the current strategies and challenges facing CAR-based immunotherapy, please see Lee DW et al., Clinical Cancer Research (In Press). Below is a summary of cell surface molecules expressed by pediatric cancers that are candidates for immune based targeting. Those targets that are the focus of substantial current research are discussed in the text, while a more complete listing is provided in Table $\mathbf{1 .}$

\section{CANDIDATE CELL SURFACE IMMUNE TARGETS EXPRESSED ON HEMATOLOGIC MALIGNANCIES OF CHILDHOOD CD19}

CD19 is an ideal immune target, being universally expressed by acute lymphoblastic leukemia, the most common malignancy of children, whereas expression on non-tumor tissues is restricted to B-cells and their progenitors but not hematopoietic stem cells (Nadler et al., 1983, 1984). Despite this favorable tissue distribution, early studies with unconjugated anti-CD19 monoclonal antibodies and anti-CD19 immunotoxins against CD19+ lymphomas were ineffective (Stone et al., 1996; Furman et al., 2011; Schindler et al., 2011). Recently however, a variety of new therapies targeting CD19 have shown promise. Blinatumomab (anti-CD19 BiTE) is a bi-specific antibody that binds CD19 and CD3, thus activating $\mathrm{T}$ cells in close proximity to $\mathrm{CD} 19^{+}$lymphoblasts. This agent showed antitumor activity in adults with B-cell lymphoma (Bargou et al., 2008), and in adult ALL patients treated with minimal residual disease, 16/21 patients had clearance of leukemia after blinatumomab monotherapy (Topp et al., 2011). Of four patients who suffered a relapse following blinatumomab, two were in sanctuary sites (testis, brain), and two relapsed with CD19- ALL, suggesting that tissue penetration and the development of antigen negative variants could pose a challenge for monotherapy with this agent (Topp et al., 2011). Reversible neurotoxicity was also observed in two patients (Topp et al., 2011). A Phase II trial enrolling adult patients with relapsed/refractory adult ALL with at least $5 \%$ bone marrow blasts is currently underway (NCT01209286), but pediatric studies have not yet been initiated.

Anti-CD19 CAR therapies have also induced robust clinical responses in CD19 expressing malignancies. Remissions have now been documented in refractory B-cell lymphoma and CLL after administration of lymphodepleting chemotherapy followed by infusion of T cells transduced to express anti-CD19 CAR (Kochenderfer et al., 2010; Kalos et al., 2011; Porter et al., 2011). These 


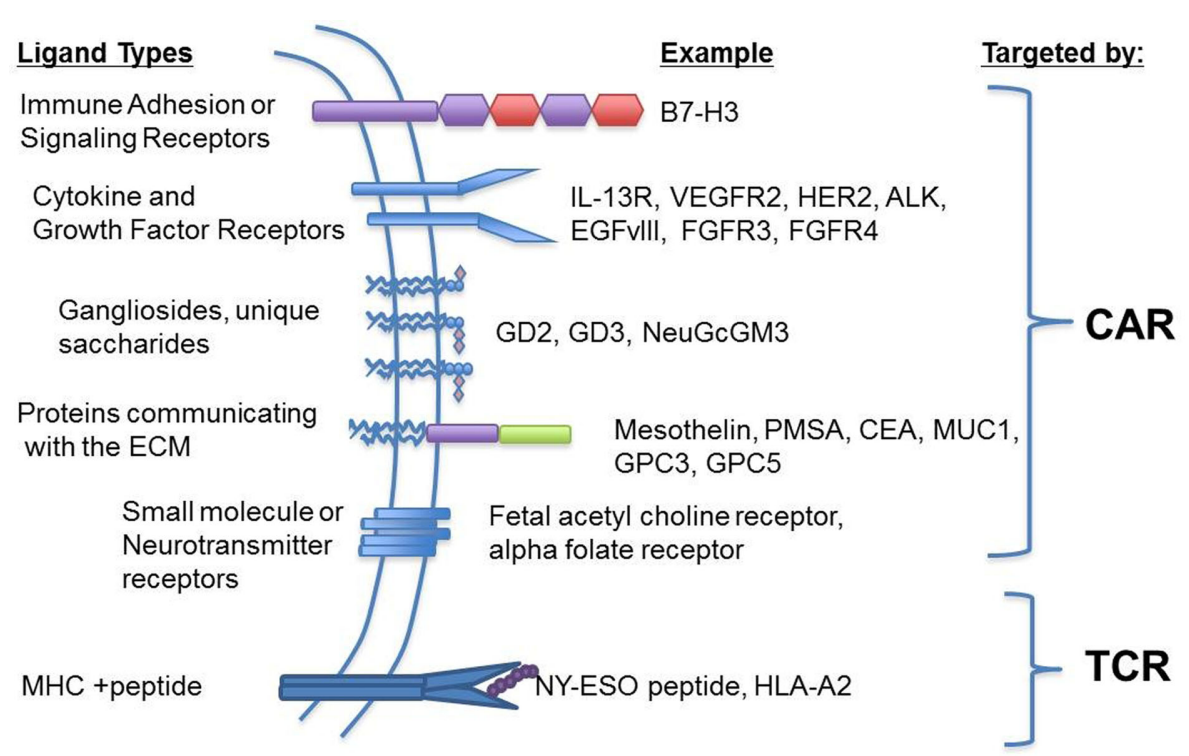

FIGURE 1 | Chimeric antigen receptors provide for expanded targeting opportunities compared to $\mathbf{T}$ cell receptors. Chimeric antigen receptors (CARs) combine a variety of antigen-recognition strategies with the functionality of the T cell receptor and a co-stimulatory signal (i.e., Signal 2) and eliminates $\mathrm{MHC}$ restriction. This potentially allows for the targeting of any extracellular moiety such as signaling or cytokine receptors, cell adhesion molecules, gangliosides, or other proteins communicating with the extracellular matrix. In contrast, the classic T cell receptor recognizes processed peptides in the context of $\mathrm{MHC}$ providing a strategy for targeting intracellular, immunogenic antigens. studies provide proof-of-principle that anti-CD19 CAR therapies can mediate impressive antitumor effects. Yet many questions remain regarding the optimal methods for generating CAR T cells, optimal preparative regimens, whether concurrent cytokine therapy improves outcomes and the relative importance of specific $\mathrm{T}$ cell subsets in mediating antitumor effects. Two pediatric studies are currently using anti-CD19 CARs to treat ALL (NCT00840853 and NCT01430390). Both administer virus-specific T cells transduced with the anti-CD19 CAR, an approach that substantially extends the time it takes to generate the cells, but could translate into improved persistence as demonstrated using GD2-CAR $\mathrm{T}$ cells (Pule et al., 2008). While the elimination of normal Bcells has been observed in adult CD19 CAR trials similar to patients who receive the anti-CD20 monoclonal antibody, rituximab, patients tend to tolerate this on-target side effect with appropriate supportive care. In fact, the constant production of B-cells by $\mathrm{CD}_{19}{ }^{-}$progenitors may provide chronic, low-level stimulation to transferred anti-CD19 CAR T cells thereby potentially contributing to persistence and long-term surveillance for leukemia relapse. It is anticipated that several more trials will open soon using anti-CD19 CAR T cells to treat pediatric ALL, using a variety of CAR constructs, $\mathrm{T}$ cell populations and treatment schemas.

\section{CD22}

CD22 is also universally expressed on pediatric ALL blasts and its expression is also restricted to the B-cell compartment (Campana et al., 1985; Gudowius et al., 2006). Epratuzumab, an unconjugated anti-CD22 antibody, was not sufficient as a single agent to achieve clinical responses in pediatric ALL, but when combined with four-drug re-induction chemotherapy 9/18 patients achieved a CR with seven of those nine MRD negative (Raetz et al., 2008). Phase II studies of epratuzumab alone and in combination with other chemotherapy regimens and haploidentical NK cell infusions are underway. Because CD22 is efficiently internalized (in contrast to CD19; Chan et al., 1998) and since internalization is important for the efficacy of immunotoxins, there has also been substantial interest in the development of anti-CD22 immunotoxins. Moxetumomab pasudotox, a high-affinity anti-CD22 antibody conjugated to pseudomonas exotoxin, has induced complete responses in $4 / 17$ (24\%) patients with refractory and relapsed pediatric ALL and most patients showed evidence for antitumor activity with little toxicity (Wayne et al., 2010; NCT00659425). Inotuzumab ozogamycin is another anti-CD22 immunotoxin also under study in patients 16 years of age and older with ALL and B-cell lymphoma (NCT01134575). This immunotoxin uses the same calicheamicin derivative found in Mylotarg (gemtuzumab ozogamicin).

Combotox, a 1:1 mixture of anti-CD19 and anti-CD22 antibodies conjugated to deglycosylated ricin-A chain has recently shown hematologic activity in 10/17 children with refractory ALL, of which three were complete responses (Herrera et al., 2009). Similarly, hematologic activity was observed in adults with ALL, although dose limiting capillary leak syndrome was observed (Schindler et al., 2011). Combotox is currently being investigated in adult ALL to determine the MTD when co-administered with 3 days of high-dose cytarabine ( $4 \mathrm{~g} / \mathrm{m}^{2} /$ day; NCT01408160). DT2219ARL is another bi-specific antibody targeting CD19 and CD22 that is conjugated to diphtheria toxin and is also currently under study in pediatric ALL (NCT00889408; Vallera et al., 2009). Finally, anti-CD22 CAR T cell therapy is being actively pursued with some preclinical activity reported (James et al., 2008). 


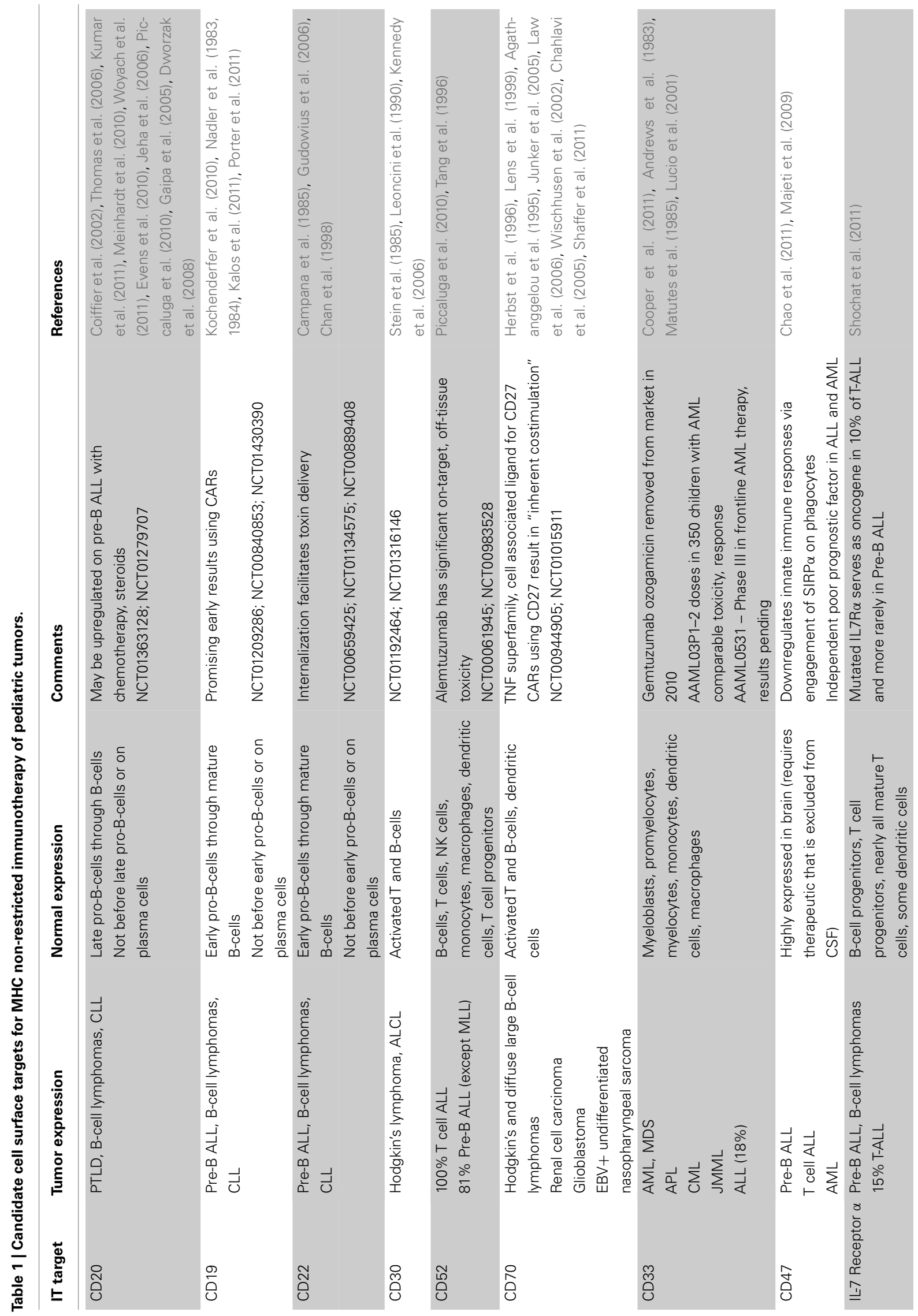



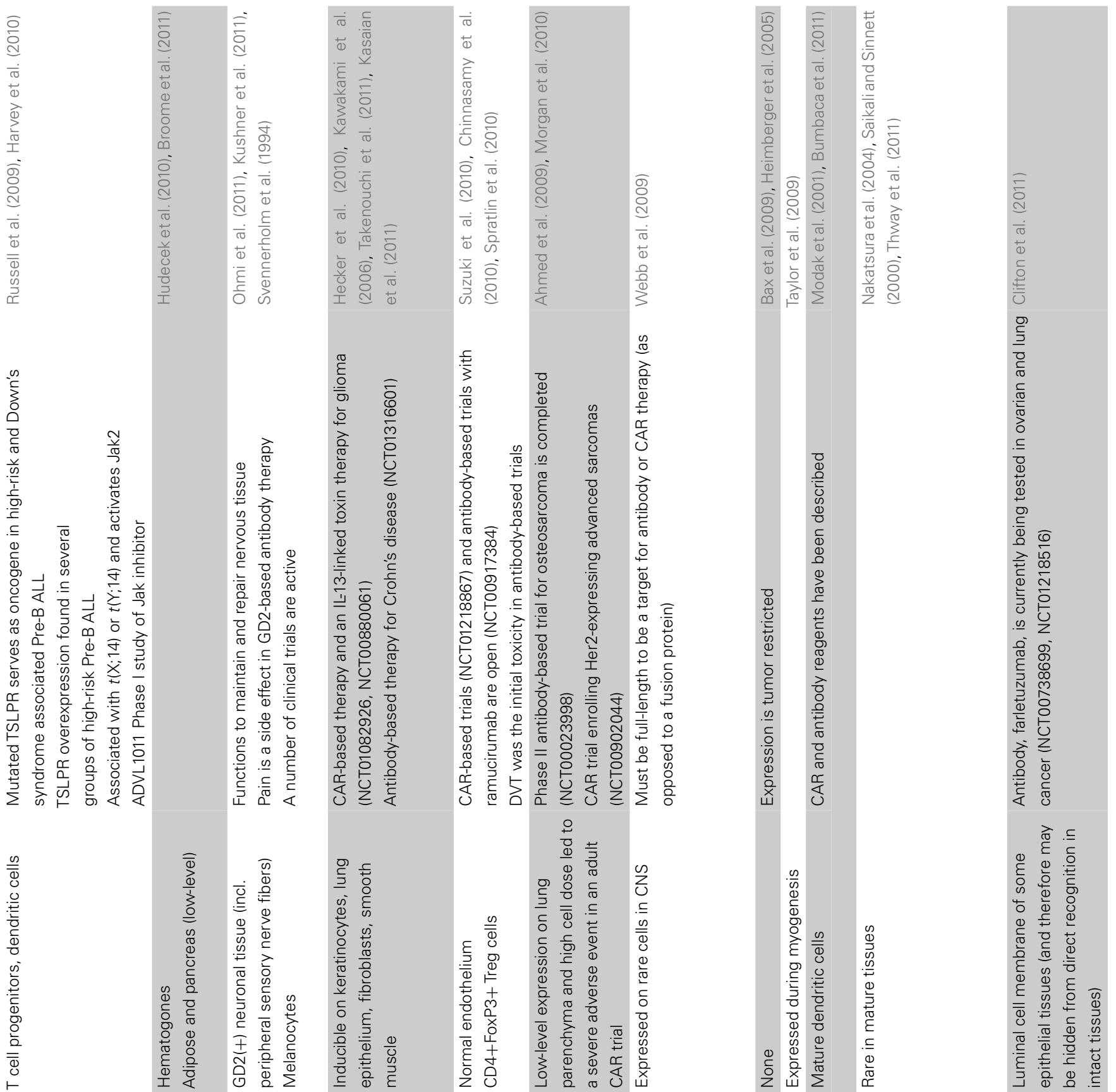

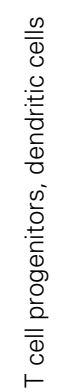
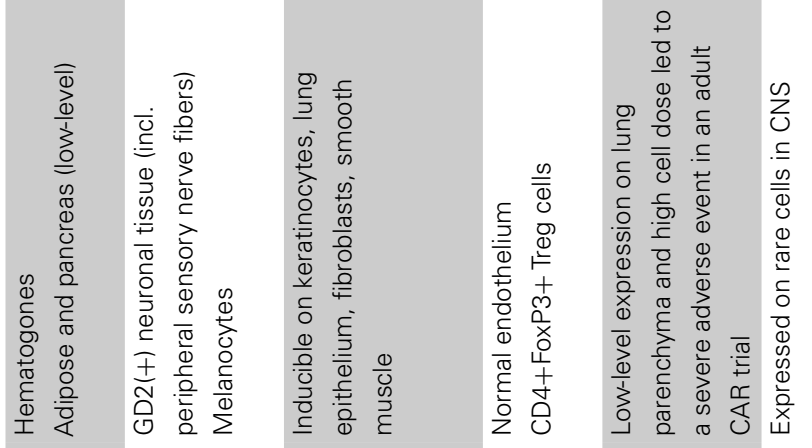

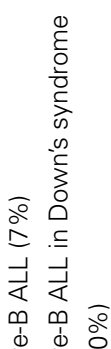
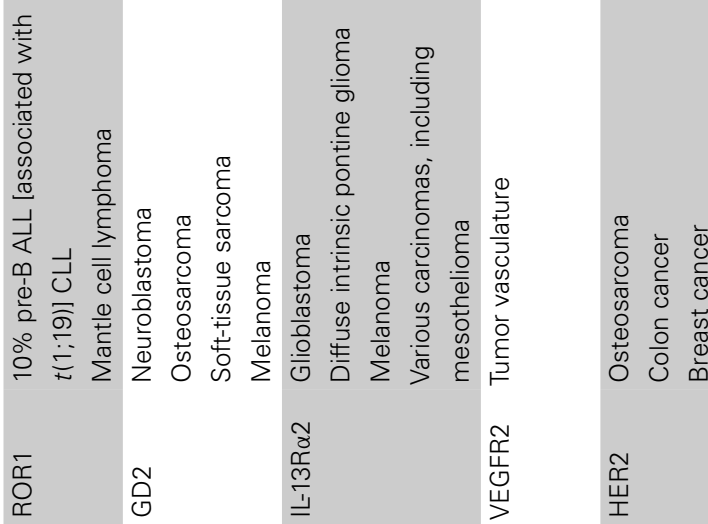

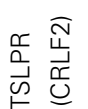
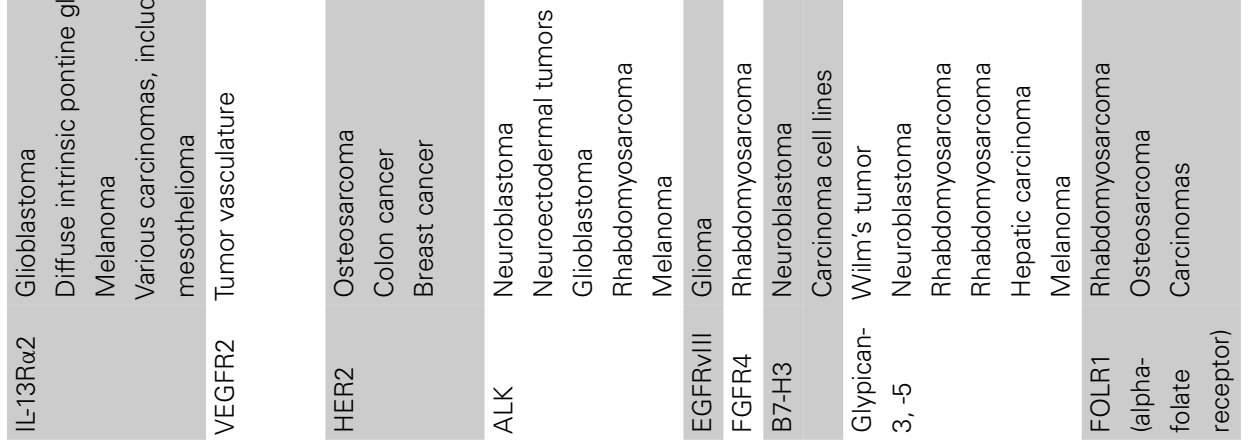


\section{CD20}

Rituximab $\left(\right.$ Rituxan $^{\circledR}$ ), an anti-CD20 monoclonal antibody, was the first approved for use in human cancer and remains one of the most successful immunologics in cancer therapy. Rituximab is now integrated into standard therapies for B-cell lymphomas (Coiffier et al., 2002; Thomas et al., 2006; Meinhardt et al., 2010; Kumar et al., 2011), chronic lymphocytic leukemia (Woyach et al., 2011), post-transplant lymphoproliferative disorder (Evens et al., 2010), and various autoimmune diseases (Stasi et al., 2001; Leah, 2011). Despite substantial depletion of normal B-cells following rituximab therapy, immunosuppression has not limited its use and Bcell numbers return to baseline within 3-6 months of completion of therapy (Thomas et al., 2006; Griffin et al., 2009). Not surprisingly, a variety of anti-CD20 based radioconjugates (Zinzani et al., 2008; Witzig et al., 2011) and CARs have also been successfully developed for adult malignancies (Till et al., 2008). In pediatric Bcell malignancies however, anti-CD20 therapies have had a limited role since neither ALL nor pediatric B-cell lymphomas commonly express CD20. (Jeha et al., 2006; Piccaluga et al., 2010) Interestingly though, recent data suggests that CD20 may be upregulated on ALL blasts after induction chemotherapy or with steroids, providing rationale for renewed efforts at the immunotherapeutic targeting of CD20 in pediatric ALL (Gaipa et al., 2005; Dworzak et al., 2008; NCT01363128; and NCT01279707).

\section{CD52}

Alemtuzumab (Campath ${ }^{\circledR}$ ) is a humanized monoclonal antibody to CD52 approved for use in adults with chronic lymphocytic leukemia. CD52 is expressed on essentially all T cell ALL blasts and the vast majority of B-cell ALL cases also show high-level CD52 expression (Piccaluga et al., 2010). Despite this, alemtuzumab as a single agent has limited activity in patients with refractory pediatric ALL (Angiolillo et al., 2009). Furthermore, CD52 is widely expressed throughout the hematopoietic system, including B-cells, T cells, NK cells, monocytes, macrophages, dendritic cells (DC), neutrophils, and mast cells. As a result, treatment with alemtuzumab is myelosuppressive and immunosuppressive (Tang et al., 1996), which limits enthusiasm for combining it with other therapies. Nevertheless, trials are underway to explore the efficacy of adding alemtuzumab to intensification or clofarabine in adolescents and adults with ALL (NCT00061945; NCT00983528). Perhaps the most important role for alemuzumab in pediatric hematology/oncology is as an adjunct to bone marrow transplantation, where it has been shown to enhance engraftment and diminish graft-versus-host disease (Flynn and Byrd, 2000; Shah et al., 2007).

\section{CD30}

CD30 is expressed by anaplastic large cell lymphoma (ALCL) and Reed-Sternberg cells in Hodgkin lymphoma (HL; Stein et al., 1985; Leoncini et al., 1990). A member of the TNF receptor superfamily, CD30 is also expressed by activated and memory T cells, and activated B-cells, where it mediates a complex myriad of activation and regulatory signals via NF- $\mathrm{B}$ (Kennedy et al., 2006; Angiolillo et al., 2009). Early attempts to treat HL and ALCL with unconjugated anti-CD30 antibodies were largely unsuccessful (Ansell et al., 2007; Forero-Torres et al., 2009). However, recently, Younes and colleagues reported impressive results following treatment of patients with refractory $\mathrm{CD} 30^{+}$lymphomas with brentuximab vedotin, an anti-CD30 antibody conjugated to the antitubulin agent monomethyl auristatin E. Brentuximab vedotin engages CD30 on the Reed-Sternberg cells and is internalized where its toxin is cleaved, arresting the cell cycle. $36 / 42 \mathrm{HL}$ patients receiving brentuximab vedotin had tumor regression, of which 11 had complete responses while $2 / 2$ additional complete responses were seen in ALCL patients (Younes et al., 2010). Together, this illustrates that even in the face of disappointing results with unconjugated antibodies, improved efficacy can be attained by using antibodies to direct the delivery of a toxic or cellular payload. To that end, CARs targeting CD30 are currently under study (NCT01192464; NCT01316146), but results have not yet been reported.

\section{CANDIDATE CELL SURFACE IMMUNE TARGETS EXPRESSED ON SOLID TUMORS OF CHILDHOOD GANGLIOSIDES}

GD2's precise role in cell biology remains unclear, but it appears to represent a developmental antigen, since it is expressed on mesenchymal stem cells derived from bone marrow, adipose, and umbilical cord blood (Jin et al., 2006). The GD2 ganglioside is overexpressed on neuroblastoma, melanoma, and some sarcomas (Schulz et al., 1984; Navid et al., 2010) and recent, definitive studies demonstrated that anti-GD2 antibody therapy improves survival in high-risk neuroblastoma (Yu et al., 2010). GD2 on neuroblastoma has also been targeted in clinical trials using first generation CARs with some evidence for clinical activity (Park et al., 2007; Pule et al., 2008) and persistence (Louis et al., 2011). More recent preclinical studies demonstrated improved efficacy of GD2-CARs with the addition of chemokine receptors that improve homing to tumor (Craddock et al., 2010). In both monoclonal antibody and anti-GD2 CAR trials, targeting GD2 has been deemed safe.

Other gangliosides also represent attractive immune targets in pediatric oncology. GD3 is a disialoganglioside that is not expressed on normal tissues, but can be found on the surface of melanoma, soft-tissue sarcoma, and tumors of neuroectodermal origin (Hamilton et al., 1993). High tumor growth rates correlate with high-levels of GD3 synthesis (Ravindranath et al., 2007). First and second generation anti-GD3 CARs induce anti-tumor effects in animal models of melanoma (Lo et al., 2010). Finally, $N$-glycoylated gangliosides incorporate $N$-glycoyl, a molecule not produced by human cells but thought to be derived from diet, then incorporated into the tumor cell surface as a result of a response to hypoxia (Scursoni et al., 2010; Bernstein, 2011). N-glycoyl$\mathrm{GM}_{3}$ was recently described to be present on the surface of Wilms' tumor, neuroblastoma, and Ewing sarcoma (Mulens et al., 2010). Since $N$-glycoylated gangliosides are not expressed by any normal tissue, these molecules may provide an ideal target for toxin and/or CAR-based immunotherapies.

\section{GROWTH FACTOR RECEPTORS AND ONCOGENES IL-13R $\alpha 2$}

IL-13 is a Th2 cytokine that can bind to the low affinity IL$13 \mathrm{R} \alpha 1$ receptor, that signals in conjunction with IL-4R $\alpha$, or a high-affinity IL-13R $\alpha 2$ receptor that binds and internalizes the 
cytokine on its own (Wynn, 2003). The low affinity receptor complex activates Jak-STAT pathways of signal transduction while the high-affinity receptor, the normal expression of which is limited to lung epithelial cells and fibroblasts at low-levels that increase with injury (Kawakami et al., 2006; Hecker et al., 2010), signals through the AP-1 transcription factor and induces production of TGF $\beta$ (Fichtner-Feigl et al., 2006). A wide array of tumors express IL-13R $\alpha 2$, including $80 \%$ of glioblastomas, most diffuse intrinsic pontine gliomas as well as melanoma and renal cell, prostate, ovarian, and pancreatic carcinomas (Kioi et al., 2008; Takenouchi et al., 2011). Preferential expression on tumor cells has led to targeting by a variety of immunotherapeutics, including a fusion protein between IL-13 and pseudomonas exotoxin (cintredekin besudotox), which failed to show enhanced efficacy compared to a standard therapy when regionally delivered in glioblastoma multiforme (Kioi et al., 2008; Kunwar et al., 2010), but studies are continuing in pediatric diffuse intrinsic pontine glioma (NCT0088006). Jensen and colleagues reported antitumor effects in a glioblastoma xenograft model of CAR transduced T cells using an affinity enhanced IL-13 instead of antibody-based motifs to direct T cell targeting (Oshima et al., 2000; Kahlon et al., 2004).

\section{VASCULAR ENDOTHELIAL GROWTH FACTOR RECEPTOR 2}

VEGFR2 (Flk-1/KDR), a transmembrane tyrosine kinase, is the primary cellular receptor for vascular endothelial growth factor (VEGF). VEGFR2 is unique among tumor targets since it is expressed on tumor vasculature instead of the tumor itself, as well as on regulatory $\mathrm{T}$ cells (Brown et al., 1993). Mouse models of malignancy originally identified $\mathrm{CD}^{+} \mathrm{T}$ cell clones specific for VEGFR2-derived peptides that could inhibit tumor angiogenesis and growth (Dong et al., 2006; Suzuki et al., 2010). VEGFR2specific CARs have demonstrated antitumor activity in murine models (Chinnasamy et al., 2010) and a clinical trial is currently underway (NCT01218867). While the potential for targeting both $\mathrm{T}$ regulatory cells and tumor vasculature is compelling, caution in immune based targeting of VEGFR2 should be exercised as it is expressed at lower levels on normal blood vessels and other tissues and is upregulated on blood vessels during wound healing (Chinnasamy et al., 2010; Edelbauer et al., 2010). In addition, elimination of $\mathrm{T}$ regulatory cells may lead to autoimmunity.

\section{HER2/Neu (ERBB2)}

Monoclonal antibody-based targeting of the amplified human epidermal growth factor receptor $2(\mathrm{HER} 2 / \mathrm{Neu})$ oncogene with trastuzumab (Herceptin ${ }^{\circledR}$ ), in breast cancer has been a major success of tumor immunotherapy (Gonzalez-Angulo et al., 2006). Although not clearly credentialed as an oncogene in pediatric cancers (Gilbertson, 2005), Her2/Neu is expressed on Wilms' tumor, medulloblastoma, and osteosarcoma but at levels that are not sufficient for antitumor effects using trastuzumab (Ragab et al., 2010). However, investigators have demonstrated activity of antiHer2/Neu CARs created using the trastuzumab binding motif (Ahmed et al., 2009; Zhao et al., 2009). Thus the threshold of expression required for targeting cells with CARs may be lower than that for monoclonal antibodies. Unfortunately, the first clinical trial of an anti-Her2/Neu CAR in adult cancer was associated with a fatal adverse event (Morgan et al., 2010), likely related to a combination of high T cell dose and low-level Her2/Neu expression in the lung, which resulted in massive cytokine release. This event does not necessarily preclude future immune targeting of ERBB2, as lower cell doses or different combinations of signaling motifs may ultimately prove to be safe. In fact, a phase I trial of anti-Her2/Neu CAR therapy in osteosarcoma using a cautious dose escalation scheme is currently underway and substantial toxicity has not been observed so far (NCT00902044).

\section{ANAPLASTIC LYMPHOMA KINASE}

Anaplastic lymphoma kinase (ALK), a receptor tyrosine kinase in the insulin receptor superfamily, was first discovered as a partner with nucleophosmin in the oncogenic fusion protein found in ALCLs (Webb et al., 2009). During neuronal development, ALK is expressed as a transmembrane protein, then downregulated soon after birth. In mature animals, ALK shows restricted CNS expression, limited to rare neurons, pericytes, and endothelial cells (Pulford et al., 1997; Falini et al., 1999). The true ligand for ALK is still in question as some studies implicate pleiotrophin/midkine, while others do not (Moog-Lutz et al., 2005; Wellstein and Toretsky, 2011). In either case, a double knockdown of ALK and pleiotrophin blocks glioma tumorigenesis. (Grzelinski et al., 2009) Full-length, cell surface ALK expression is observed in a wide array of tumors including lung cancer, neuroblastoma, neuroectodermal tumors, glioblastoma, rhabdomyosarcoma, and melanoma (Webb et al., 2009) and recently ALK was identified as an oncogene in both familial and sporadic neuroblastoma (George et al., 2008; Mosse et al., 2008). Thus, ALK represents a promising target for both oncogene-inhibition and immunotherapy.

\section{EGFRvIII}

A mutant, constitutively activated form of the epidermal growth factor receptor, EGFRvIII, is overexpressed on the surface of approximately $20 \%$ of adult and pediatric gliomas (Heimberger et al., 2005; Bax et al., 2009). EGFRvIII has been targeted with T cell based immunotherapy as a vaccine (Sampson et al., 2010), and in addition, CAR vectors targeting EGFRvIII have been produced and validated in vitro, and clinical trials are awaited (Bullain et al., 2009; Ohno et al., 2010). Like ALK, the potential role of EGFRvIII in the growth/survival of these tumors makes it a promising target for both oncogene-inhibition and immunotherapy.

\section{FIBROBLAST GROWTH FACTOR RECEPTOR 4}

There are over 20 known fibroblast growth factors, the activity of which are mediated by four distinct receptors. Fibroblast growth factors play myriad roles in cell signaling, growth and differentiation, and mutations or alterations in this system have been described in a number of malignancies (Olsen et al., 2003; Wesche et al., 2011). Antibodies to fibroblast growth factor receptor 3 (FGFR3) are currently undergoing trials in multiple myeloma (NCT00866138). FGFR4 is a new target identified in pediatric solid tumors that is overexpressed by nearly all rhabdomyosarcomas with activating point-mutations observed in more aggressive disease (Taylor et al., 2009; Paulson et al., 2011) and with limited expression on normal myocytes. Thus, it also serves as a candidate target for both oncogene-inhibition and immunotherapy. 


\section{OTHER CELL SURFACE MOLECULES 4lgB7-H3}

Most adhesion receptors are broadly expressed, but some such as $\mathrm{B} 7-\mathrm{H} 3$ are expressed in a more restricted fashion, and thus offer the potential for immune targeting in cancer. B7-H3 has two isoforms; the $2 \mathrm{Ig}-\mathrm{B} 7-\mathrm{H} 3$ isoform is expressed on mature DC and a number of carcinoma cell lines (Zhang et al., 2005) but has not been reported on pediatric tumors. However, the 4Ig-B7-H3 isoform is expressed on neuroblastoma (Castriconi et al., 2004) and has been reported to be the target of $8 \mathrm{H} 9$ (Xu et al., 2009), a monoclonal antibody which binds to a wide array of pediatric tumors, including sarcomas and most brain tumors (Modak et al., 2001, 2002). Masking of 4Ig-B7-H3 enhances NK cell lysis of neuroblastoma cell lines, suggesting that it may negatively regulate NK signaling (Castriconi et al., 2004). Clinical studies are currently underway using radioconjugated $8 \mathrm{H} 9$ for treatment of intraperitoneal desmoplastic small round cell tumor (NCT01099644) as well as for leptomeningeal spread of 8H9 binding tumors (NCT00089245). Due to concerns regarding hepatic expression of the $8 \mathrm{H} 9$ binding antigen, systemic administration of this monoclonal antibody has not been pursued. It remains unclear whether hepatic expression of $4 \mathrm{IgB} 7-\mathrm{H} 3$ will preclude systemic targeting of this antigen.

\section{GLYPICANS}

Glypican-3 is a cell surface peptidoglycan found on the surface of hepatocellular carcinoma and melanoma, and glypican-3 mRNA has been demonstrated on embryonal tumors including neuroblastoma and Wilms' tumor (Saikali and Sinnett, 2000; Nakatsura et al., 2004). Recently, a homologous molecule, glypican-5 was demonstrated to be amplified in rhabdomyosarcoma and to play a role in growth/survival of this tumor (Williamson et al., 2007). Thus, at least two glypican family of molecules represent potential targets in embryonal tumors.

\section{ALPHA-FOLATE RECEPTOR}

A humanized antibody specific for alpha-folate receptor (FOLR1), farletuzumab, is currently in clinical trials for patients with ovarian carcinoma (Konner et al., 2010). The expression of this transmembrane folate receptor in normal tissues is limited to the luminal side of epithelium and therefore is not accessible to the vascular system and would not be targeted by monoclonal antibody therapies (Garin-Chesa et al., 1993; Ross et al., 1994). Analyses contained within the public tissue expression database ${ }^{1}$ document overex-

${ }^{1}$ http://home.ccr.cancer.gov/oncology/oncogenomics/

Table 2 | Non-CTA, MHC restricted immune targets expressed in pediatric cancer.

\begin{tabular}{|c|c|c|c|}
\hline Class/target & Expression & Notes & References \\
\hline \multicolumn{4}{|c|}{ DIFFERENTIATION ANTIGENS } \\
\hline Proteinase-3 (PR-3) & AML $(M 2, M 3>M 4>M 1)$ & $\begin{array}{l}\text { PR-1 is a PR-3 derived peptide that has } \\
\text { elicited immune responses in clinical trials }\end{array}$ & $\begin{array}{l}\text { Dengler et al. (1995), Molldrem et al. } \\
\text { (1996), Rezvani (2008) }\end{array}$ \\
\hline $\begin{array}{l}\text { Hyaluronic acid-mediated } \\
\text { motility (RHAMM, CD168) }\end{array}$ & $\approx 70 \% \mathrm{AML}$ & $\begin{array}{l}\text { Limited data on pediatric versus adult } \\
\text { leukemias }\end{array}$ & Greiner et al. (2002, 2003) \\
\hline $\begin{array}{l}\text { STEAP (six-transmembrane } \\
\text { epithelial antigen of } \\
\text { prostate) }\end{array}$ & Ewing sarcoma & $\begin{array}{l}\text { Data too limited to denote approximate } \\
\text { percentage }\end{array}$ & $\begin{array}{l}\text { Hu-Lieskovan et al. (2005), Hubert et al. } \\
\text { (1999) }\end{array}$ \\
\hline \multicolumn{4}{|l|}{ ONCOGENES } \\
\hline Flt3-ITD & $\approx 25 \%$ Pediatric AML & HLA-A1 epitope identified & Brown et al. (2004) \\
\hline Her2/Neu & $\begin{array}{l}\approx 60 \% \text { Osteosarcoma* } \\
\approx 40 \% \text { Medulloblastoma }\end{array}$ & & $\begin{array}{l}\text { Gilbertson (2005), Ahmed et al. (2009), Gor- } \\
\text { lick et al. (1999), Hughes et al. (2004), } \\
\text { Ahmed et al. (2007), Tong et al. (2004) }\end{array}$ \\
\hline WT1 & $\begin{array}{l}\approx 70-80 \% \text { AML } \\
\approx 60-80 \% \text { ALL } \\
\approx 100 \% \text { Rhabdomyosarcoma } \\
\approx 50 \% \text { ESFT }\end{array}$ & $\begin{array}{l}\text { HLA-A1, A24, DP5, DR4 epitopes } \\
\text { identified }\end{array}$ & $\begin{array}{l}\text { Inoue et al. (1997), Rosenfeld et al. (2003), } \\
\text { Ohta et al. (2009), Nakatsuka et al. (2006) }\end{array}$ \\
\hline Survivin & All tumors & $\begin{array}{l}\text { Fratricide reported by high-affinity } \\
\text { survivin-specific CTLs due to T cell } \\
\text { survivin expression }\end{array}$ & $\begin{array}{l}\text { Leisegang et al. (2010), Coughlin et al. } \\
\text { (2004, 2006), Rapoport et al. (2011) }\end{array}$ \\
\hline Telomerase (hTERT) & All tumors & & Rapoport et al. (2011) \\
\hline BCR-ABL (p210) & $100 \% \mathrm{CML}$ & HLA-A2, B8, DR4, DR9 epitopes identified & Yotnda et al. (1998a) \\
\hline PAX3-FKHR & $\begin{array}{l}\approx 90 \% \text { Alveolar } \\
\text { rhabdomyosarcoma }\end{array}$ & HLA-B7 epitope identified & van den Broeke et al. (2006) \\
\hline SYT-SSX1, SSX2 & $100 \%$ Synovial sarcoma & HLA-B7 epitope identified & Worley et al. (2001) \\
\hline ETV6-AML1 & $\approx 25 \% \mathrm{ALL}$ & $\begin{array}{l}\text { HLA-A2, HLA-DP5, HLA-DP17 epitopes } \\
\text { identified }\end{array}$ & Yotnda et al. (1998b) \\
\hline PML-RAR $\alpha$ & $100 \%$ M3-AML & HLA-DR11 epitope identified & Gambacorti-Passerini et al. (1993) \\
\hline
\end{tabular}

* Expression in osteosarcoma is not associated with amplification as observed in Her2/Neu expressing breast carcinomas. 
pression in some pediatric tumors as well, including osteosarcoma and Ewing's sarcoma. CAR-based cell therapies targeting FOLR1 are underway and could potentially be extended to FOLR1 pediatric tumors (Kershaw et al., 2006).

\section{MHC RESTRICTED IMMUNE TARGETS IN PEDIATRIC CANCER WILMS' TUMOR ANTIGEN}

Wilms' tumor antigen (WT1) is expressed by several pediatric tumors, and appears to be immunogenic (Cheever et al., 2009). Some concerns remain regarding expression on hematopoietic stem cells, renal podocytes, and potentially other cycling populations, but the community remains optimistic that WT1 may prove to be an effective tumor antigen, as it was ranked the most promising of all tumor antigens by the NCI (Cheever et al., 2009). Several small, non-randomized studies have demonstrated WT1 specific immunity following peptide based vaccination and in some cases this was associated with evidence for anti-leukemic activity. An ongoing vaccine trial is underway for patients with recurrent leukemias and lymphoma at the NCI Pediatric Oncology Branch (NCT00923910).

\section{SURVIVIN}

Survivin is an anti-apoptotic molecule that is overexpressed in most tumors, but also has widespread low-level expression in normal tissues. Survivin-specific T cells have been isolated from patients with cancer, including neuroblastoma, and some groups have demonstrated that survivin-specific $\mathrm{T}$ cells can mediate tumor lysis (Cheever et al., 2009). Based upon these results, several investigators sought to develop high-affinity survivin-specific T cells. Remarkably, such cells are able to lyse nearly all tumors but also mediate fratricide of normal $\mathrm{T}$ cells due to survivin expression following activation (Leisegang et al., 2010). Thus, normal tissue expression of survivin appears likely to limit the effectiveness of immunotherapies targeting this antigen and similar limitations could apply to other broadly expressed tumor antigens.

Several other non-cancer testis antigens that are candidate MHC restricted $\mathrm{T}$ cell targets expressed in pediatric tumors are shown in Table 2.

\section{CANCER-TESTIS ANTIGENS}

Cancer testis antigens [also referred to as cancer germline genes (CGG)] are expressed in a wide array of cancers, with normal tissue expression limited to testicular germ cells and placental trophoblasts (see detailed reviews Fratta et al., 2011 and detailed listing of the genes at http://www.cta.lncc.br). The first tumor antigen identified, MAGE-A1, is a prototype and since its discovery the family has expanded to comprise 70 families with over 140 antigens. Over half of the CTAs are encoded by the X chromosome (X-CTA) and it is estimated that approximately $10 \%$ of the $\mathrm{X}$ chromosome encodes for these molecules. Expression is regulated in large part by epigenetic factors, although the BORIS transcription factor has also been shown to be a potent inducer of their expression (Fratta et al., 2011). The biologic function of CTAs has remained elusive and their scientific interest has been primarily based upon their inherent immunogenicity and their restricted tissue expression, which has made them compelling immune targets.

The CTA family officially encompasses a vast number of molecules (Almeida et al., 2009), but a much smaller number have been demonstrated to be immunogenic and thus are truly promising targets for immunotherapies (detailed in http://www.cancer immunity.org/peptidedatabase/tumorspecific.htm). Furthermore, analysis of CTAs in pediatric tumors has been limited (Liu et al., 2000; Zendman et al., 2002; Foell et al., 2008; Jacobs et al., 2008; Oba-Shinjo et al., 2008; Grau et al., 2009; Pollack et al., 2011). A summary of the studies reporting CTAs in pediatric tumors is shown in Table 3, but several caveats should be emphasized. First, most studies involve limited numbers of tumors, which are not adequate to reliably define the percent of tumors of any specific histology expressing CTAs, and most studies have not been confirmed. Thus, the prevalence of expression listed for any histology must be considered an approximation at best.

Second, whereas NY-ESO-1 and PRAME each represent one gene, the rest of the CTAs shown in Table 3 represent gene families, for which expression is likely to vary across the specific genes

Table 3 | Cancer testis antigens in pediatric tumors.

\begin{tabular}{|c|c|c|}
\hline Antigen & RNA expression $\infty$ & References \\
\hline $\begin{array}{l}\text { NY-ESO-1/ } \\
\text { LAGE-2 }\end{array}$ & $\begin{array}{l}\approx 70 \% \text { Synovial sarcoma, } \\
\approx 90 \% \text { osteosarcoma, } \\
\approx 30 \% \text { neuroblastoma, } \\
\approx 0 \% \text { ESFT, } \\
\approx 25 \% \text { rhabdomyosarcoma, } \\
\approx 40 \% \text { ependymoma, } \\
\approx 10 \% \text { medulloblastoma }\end{array}$ & $\begin{array}{l}\text { Jacobs et al. (2007), Rob- } \\
\text { bins et al. (2011), Segal } \\
\text { et al. (2005), Jungbluth } \\
\text { et al. (2001) }\end{array}$ \\
\hline PRAME & $\begin{array}{l}\approx 100 \% \text { Synovial sarcoma, } \\
\approx 80 \% \text { medulloblastoma, } \\
\approx 70 \% \text { osteosarcoma, } \\
\approx 40 \% \text { pediatric acute } \\
\text { lymphoblastic leukemia, } \\
\approx 60 \% \text { pediatric acute myeloid } \\
\text { leukemia }\end{array}$ & $\begin{array}{l}\text { Segal et al. (2005), Vulcani- } \\
\text { Freitas et al. (2011), Toledo } \\
\text { et al. (2011), Steinbach } \\
\text { et al. (2006), Steinbach } \\
\text { et al. (2002), Spanaki et al. } \\
\text { (2007), Boon et al. (2003), } \\
\text { Oberthuer et al. (2004) }\end{array}$ \\
\hline MAGE A & $\begin{array}{l}\approx 0-70 \% \text { Synovial sarcoma } \\
\approx 80 \% \text { neuroblastoma, } \\
\approx 40 \% \text { rhabdomyosarcoma, } \\
\approx 50 \% \text { ESFT, } \\
\approx 100 \% \text { osteosarcoma, } \\
\approx 30-60 \% \text { glioma, } \\
\approx 20-60 \% \text { medulloblastoma, } \\
\text { ependymoma, choroid plexus }\end{array}$ & $\begin{array}{l}\text { Jacobs et al. (2007), } \\
\text { Kasuga et al. (2008) }\end{array}$ \\
\hline SSX2 & $\approx 80 \%$ Synovial sarcoma & Segal et al. (2005) \\
\hline GAGE & $\begin{array}{l}\approx 30 \% \text { Neuroblastoma, } \\
\approx 60 \% \text { ependymoma, } \\
\approx 20-80 \% \text { medulloblastoma, } \\
\approx 10 \% \text { ESFT, } \\
\approx 100 \% \text { osteosarcoma }\end{array}$ & $\begin{array}{l}\text { Steinbach et al. (2006), } \\
\text { Kasuga et al. (2008) }\end{array}$ \\
\hline XAGE-1 & $\approx 40-90 \%$ Ewing sarcoma & $\begin{array}{l}\text { Liu et al. (2000), Zendman } \\
\text { et al. (2002) }\end{array}$ \\
\hline
\end{tabular}

${ }^{\infty}$ Documentation of protein expression is limited to NY-ESO-1 in synovial sarcoma, and MAGE-A1 and A4 in limited numbers of pediatric solid tumors (Jacobs et al., 2007) and brain tumors (Jacobs et al., 2008).

${ }^{5}$ MAGE-A1 expression is absent in synovial sarcoma by immunohistochemistry (Jungbluth et al., 2001). 
within that family. For example, within the MAGE A family at least eight different immunogenic genes have been identified (A1-4, 6, 9,10 , and 12). Given that targeted immunotherapy trials typically focus on one antigen, the percent of tumors that could be targeted with any given vaccine will be limited to those tumors expressing that specific gene. Third, very few studies have incorporated immunohistochemistry or other approaches to confirm protein expression of CTAs in pediatric tumors. In the few that have, some have reported that mRNA expression correlated with protein expression (Jacobs et al., 2007), while others have noted that mRNA positivity is associated with patchy or very weak immunohistochemical staining (Oba-Shinjo et al., 2008). Together, one can conclude that CTAs are likely to be expressed in a sizable percentage of childhood cancers, but substantially more work is needed to accurately define the prevalence of CTA protein expression among pediatric histologies, to better characterize the intensity, distribution, and extent of homogeneity of CTA expression within tumors. Clarification of these issues is needed before one can accurately predict whether targeting CTAs for immunotherapy of pediatric cancer is likely to be effective.

One tumor where robust CTA protein expression has been clearly documented is synovial sarcoma. NY-ESO-1 expression is seen in approximately $70 \%$ of synovial sarcomas and is characterized by diffuse, intense protein expression. Furthermore, preliminary results demonstrate that meaningful antitumor effects can result from targeting NY-ESO-1 in these tumors, most recently using adoptive transfer of $\mathrm{T}$ cells genetically engineered to express a high-affinity NY-ESO-1 peptide specific T cell receptor (Robbins et al., 2011). Despite these exciting results, challenges in translating this therapy on a larger scale epitomize the challenges unique to $\mathrm{T}$ cell based immunotherapies. The TCR used in this therapy targets an HLA-A2 restricted peptide, and approximately $40 \%$ of

\section{REFERENCES}

Agathanggelou, A., Niedobitek, G., Chen, R., Nicholls, J., Yin, W., and Young, L. S. (1995). Expression of immune regulatory molecules in Epstein-Barr virus-associated nasopharyngeal carcinomas with prominent lymphoid stroma. Evidence for a functional interaction between epithelial tumor cells and infiltrating lymphoid cells. Am. J. Pathol. 147, 1152-1160.

Ahmed, N., Ratnayake, M., Savoldo, B., Perlaky, L., Dotti, G., Wels, W. S., Bhattacharjee, M. B., Gilbertson, R. J., Shine, H. D., Weiss, H. L., Rooney, C. M., Heslop, H. E., and Gottschalk, S. (2007). Regression of experimental medulloblastoma following transfer of HER2-specific T cells. Cancer Res. 67, 5957-5964.

Ahmed, N., Salsman, V. S., Yvon, E., Louis, C. U., Perlaky, L., Wels, W. S., Dishop, M. K., Kleinerman, E. E., Pule, M., Rooney, C. M., Heslop, H. E., and Gottschalk, S. (2009). Immunotherapy for osteosarcoma: genetic modification of $\mathrm{T}$ cells

the Caucasian population expresses HLA-A2, while lesser percentages are found in individuals of Asian and African descent. There are approximately 800 new diagnoses of synovial sarcoma each year, of which approximately 200 small tumors $(<5 \mathrm{~cm})$ have an excellent prognosis with surgery alone ${ }^{2}$. Thus, fewer than 200 new cases of synovial sarcoma per year could benefit from this exciting emerging therapy. Given the rarity of this disease, it is easy to understand why executing trials and standardizing $\mathrm{MHC}$ restricted $\mathrm{T}$ cell based therapies for rare cancers is challenging.

\section{FERTILE GROUND FOR NEW CANCER IMMUNOTHERAPEUTICS}

We have discussed the major, current attractive targets for immunotherapy in pediatric cancer taking into consideration expression on normal or vital tissues. While much progress has been made in pediatric oncology, some subgroups, such as those with metastatic sarcomas and brain tumors, have not seen major improvement in survival over the past few decades despite intensifying chemotherapies. The long-term benefit of monoclonal antibody therapy has yet to be proven and none except anti-GD2 have become standard therapy in pediatric oncology. In addition to further developing monoclonal antibody therapy, the field is moving to use the target cell specificity of antibody or antibody-like molecules as a means to deliver toxins or immune effector cells to the tumor. Advances in small molecule technology, production of new forms of antibody, and innovations in cell production techniques are responsible for recent exciting results, albeit in small numbers of patients, mostly limited to adult oncology. Still, these techniques are just now becoming applicable to the clinic and are likely to be a fertile arena for clinical progress in pediatric oncology for the next decade.

${ }^{2}$ http://sarcomahelp.org/learning_center/synovial_sarcoma.html

Oncology Group report. Pediatr. Blood Cancer 53, 978-983.

Ansell, S. M., Horwitz, S. M., Engert, A., Khan, K. D., Lin, T., Strair, R., Keler, T., Graziano, R., Blanset, D., Yellin, M., Fischkoff, S., Assad, A., and Borchmann, P. (2007). Phase I/II study of an anti-CD30 monoclonal antibody (MDX-060) in Hodgkin's lymphoma and anaplastic largecell lymphoma. J. Clin. Oncol. 25, 2764-2769.

Ascierto, P. A., Simeone, E., Sznol, M., Fu, Y. X., and Melero, I. (2010). Clinical experiences with anti-CD137 and anti-PD1 therapeutic antibodies. Semin. Oncol. 37, 508-516.

Baeuerle, P. A., and Reinhardt, C. (2009). Bispecific T-cell engaging antibodies for cancer therapy. Cancer Res. 69, 4941-4944.

Bargou, R., Leo, E., Zugmaier, G., Klinger, M., Goebeler, M., Knop, S., Noppeney, R., Viardot, A., Hess, G., Schuler, M., Einsele, H., Brandl, C., Wolf, A., Kirchinger, P., Klappers, P., Schmidt, M., Riethmüller, G., Reinhardt, C., Baeuerle, P. A., and Kufer,
P. (2008). Tumor regression in cancer patients by very low doses of a $\mathrm{T}$ cell-engaging antibody. Science 321, 974-977.

Bax, D. A., Gaspar, N., Little, S. E., Marshall, L., Perryman, L., Regairaz, M., Viana-Pereira, M., Vuononvirta, R., Sharp, S. Y., Reis-Filho, J. S., Stávale, J. N., Al-Sarraj, S., Reis, R. M., Vassal, G., Pearson, A. D., Hargrave, D., Ellison, D. W., Workman, P., and Jones, C. (2009). EGFRvIII deletion mutations in pediatric highgrade glioma and response to targeted therapy in pediatric glioma cell lines. Clin. Cancer Res. 15, 5753-5761.

Bernstein, M. L. (2011). Targeted therapy in pediatric and adolescent oncology. Cancer 117, 2268-2274.

Boon, K., Edwards, J. B., Siu, I. M., Olschner, D., Eberhart, C. G., Marra, M. A., Strausberg, R. L., and Riggins, G. J. (2003). Comparison of medulloblastoma and normal neural transcriptomes identifies a restricted set of activated genes. Oncogene 22, 7687-7694. 
Broome, H. E., Rassenti, L. Z., Wang, H. Y., Meyer, L. M., and Kipps, T. J. (2011). ROR1 is expressed on hematogones (non-neoplastic human B-lymphocyte precursors) and a minority of precursor-B acute lymphoblastic leukemia. Leuk. Res. 35, 1390-1394.

Brown, L. F., Berse, B., Jackman, R. W., Tognazzi, K., Manseau, E. J., Dvorak, H. F., and Senger, D. R. (1993). Increased expression of vascular permeability factor (vascular endothelial growth factor) and its receptors in kidney and bladder carcinomas. Am. J. Pathol. 143, 1255-1262.

Brown, P., Meshinchi, S., Levis, M., Alonzo, T. A., Gerbing, R., Lange, B., Arceci, R., and Small, D. (2004). Pediatric AML primary samples with FLT3/ITD mutations are preferentially killed by FLT3 inhibition. Blood 104, 1841-1849.

Bullain, S. S., Sahin, A., Szentirmai, O., Sanchez, C., Lin, N., Baratta, E., Waterman, P., Weissleder, R., Mulligan, R. C., and Carter, B. S. (2009). Genetically engineered $T$ cells to target EGFRvIII expressing glioblastoma. J. Neurooncol. 94, 373-382.

Bumbaca, D., Wong, A., Drake, E., Reyes AE, 2. n. d., Lin, B. C., Stephan, J. P., Desnoyers, L., Shen, B. Q., and Dennis, M. S. (2011). Highly specific offtarget binding identified and eliminated during the humanization of an antibody against FGF receptor 4 . MAbs 3, 376-386.

Campana, D., Janossy, G., Bofill, M., Trejdosiewicz, L. K., Ma, D., Hoffbrand, A. V., Mason, D. Y., Lebacq, A. M., and Forster, H. K. (1985). Human B cell development. I. Phenotypic differences of $\mathrm{B}$ lymphocytes in the bone marrow and peripheral lymphoid tissue. J. Immunol. 134, 1524-1530.

Castriconi, R., Dondero, A., Augugliaro, R., Cantoni, C., Carnemolla, B., Sementa, A. R., Negri, F., Conte, R., Corrias, M. V., Moretta, L., Moretta, A., and Bottino, C. (2004). Identification of $4 \mathrm{Ig}-\mathrm{B} 7-\mathrm{H} 3$ as a neuroblastoma-associated molecule that exerts a protective role from an NK cell-mediated lysis. Proc. Natl. Acad. Sci. U.S.A. 101, 12640-12645.

Chahlavi, A., Rayman, P., Richmond, A. L., Biswas, K., Zhang, R., Vogelbaum, M., Tannenbaum, C., Barnett, G., and Finke, J. H. (2005). Glioblastomas induce T-lymphocyte death by two distinct pathways involving gangliosides and CD70. Cancer Res. 65, 5428-5438.

Chan, C. H., Wang, J., French, R. R., and Glennie, M. J. (1998). Internalization of the lymphocytic surface protein CD22 is controlled by a novel membrane proximal cytoplasmic motif. J. Biol. Chem. 273, 27809-27815.

Chao, M. P., Alizadeh, A. A., Tang, C., Jan, M., Weissman-Tsukamoto, R., Zhao, F., Park, C. Y., Weissman, I. L., and Majeti, R. (2011). Therapeutic antibody targeting of CD47 eliminates human acute lymphoblastic leukemia. Cancer Res. 71, 1374-1384.

Cheever, M. A., Allison, J. P., Ferris, A. S., Finn, O. J., Hastings, B. M., Hecht, T. T., Mellman, I., Prindiville, S. A., Viner, J. L., Weiner, L. M., and Matrisian, L. M. (2009). The prioritization of cancer antigens: a national cancer institute pilot project for the acceleration of translational research. Clin. Cancer Res. 15, 5323-5337.

Chinnasamy, D., Yu, Z., Theoret, M. R., Zhao, Y., Shrimali, R. K., Morgan, R. A., Feldman, S. A., Restifo, N. P., and Rosenberg, S. A. (2010). Gene therapy using genetically modified lymphocytes targeting VEGFR2 inhibits the growth of vascularized syngeneic tumors in mice. J. Clin. Invest. 120, 3953-3968.

Christoffersen, T., Guren, T. K., Spindler, K. L., Dahl, O., Lonning, P. E. and Gjertsen, B. T. (2009). Cancer therapy targeted at cellular signal transduction mechanisms: strategies, clinical results, and unresolved issues. Eur. J. Pharmacol. 625, 6-22.

Clifton, G. T., Sears, A. K., Clive, K. S., Holmes, J. P., Mittendorf, E. A., Ioannides, C. G., Ponniah, S., and Peoples, G. E. (2011). Folate receptor alpha: a storied past and promising future in immunotherapy. Hum. Vaccin. 7, 183-190.

Coiffier, B., Lepage, E., Briere, J., Herbrecht, R., Tilly, H., Bouabdallah, R., Morel, P., Van Den Neste, E., Salles, G., Gaulard, P., Reyes, F., Lederlin, P., and Gisselbrecht, C. (2002). CHOP chemotherapy plus rituximab compared with CHOP alone in elderly patients with diffuse large-Bcell lymphoma. N. Engl. J. Med. 346, 235-242.

Cooper, T. M., Franklin, J., Gerbing, R. B., Alonzo, T. A., Hurwitz, C., Raimondi, S. C., Hirsch, B., Smith, F. O., Mathew, P., Arceci, R. J., Feusner, J., Iannone, R., Lavey, R. S., Meshinchi, S., and Gamis, A. (2011). AAML03P1, a pilot study of the safety of gemtuzumab ozogamicin in combination with chemotherapy for newly diagnosed childhood acute myeloid leukemia: a report from the children's oncology group. Cancer.
Cortes, J., Hochhaus, A., Hughes, T., and Kantarjian, H. (2011). Front-line and salvage therapies with tyrosine kinase inhibitors and other treatments in chronic myeloid leukemia. J. Clin. Oncol. 29, 524-531.

Coughlin, C. M., Fleming, M. D., Carroll, R. G., Pawel, B. R., Hogarty, M. D., Shan, X., Vance, B. A., Cohen, J. N., Jairaj, S., Lord, E. M., Wexler, M. H., Danet-Desnoyers, G. A., Pinkus, J. L., Pinkus, G. S., Maris, J. M., Grupp, S. A., and Vonderheide, R. H. (2006). Immunosurveillance and survivin-specific T-cell immunity in children with high-risk neuroblastoma. J. Clin. Oncol. 24, 5725-5734.

Coughlin, C. M., Vance, B. A., Grupp, S. A., and Vonderheide, R. H. (2004). RNA-transfected CD40-activated $\mathrm{B}$ cells induce functional $\mathrm{T}$-cell responses against viral and tumor antigen targets: implications for pediatric immunotherapy. Blood 103, 2046-2054.

Craddock, J. A., Lu, A., Bear, A., Pule, M. Brenner, M. K., Rooney, C. M., and Foster, A.E. (2010). Enhanced tumor trafficking of GD2 chimeric antigen receptor $\mathrm{T}$ cells by expression of the chemokine receptor CCR2b. J. Immunother. 33, 780-788.

Czerniecki, B. J., Koski, G. K., Koldovsky, U., Xu, S., Cohen, P. A., Mick, R., Nisenbaum, H., Pasha, T., Xu, M., Fox, K. R., Weinstein, S., Orel, S. G., Vonderheide, R., Coukos, G. DeMichele, A., Araujo, L., Spitz, F. R., Rosen, M., Levine, B. L., June, C., and Zhang, P. J. (2007). Targeting HER-2/neu in early breast cancer development using dendritic cells with staged interleukin12 burst secretion. Cancer Res. 67, 1842-1852.

Dengler, R., Munstermann, U., alBatran, S., Hausner, I., Faderl, S., Nerl, C., and Emmerich, B. (1995). Immunocytochemical and flow cytometric detection of proteinase 3 (myeloblastin) in normal and leukaemic myeloid cells. $\mathrm{Br}$. $J$. Haematol. 89, 250-257.

Dhomen, N., and Marais, R. (2009). BRAF signaling and targeted therapies in melanoma. Hematol. Oncol. Clin. North Am. 23, 529-545, ix.

Diehl, K. M., Keller, E. T., and Ignatoski, K. M. (2007). Why should we still care about oncogenes? Mol. Cancer Ther. 6, 418-427.

Dong, Y., Qian, J., Ibrahim, R., Berzofsky, J. A., and Khleif, S. N (2006). Identification of H-2Dbspecific CD8+ T-cell epitopes from mouse VEGFR2 that can inhibit angiogenesis and tumor growth. $J$. Immunother. 29, 32-40.
Dworzak, M. N., Schumich, A., Printz, D., Pötschger, U., Husak, Z., Attarbaschi, A., Basso, G., Gaipa, G., Ratei, R., Mann, G., and Gadner, H. (2008). CD20 up-regulation in pediatric Bcell precursor acute lymphoblastic leukemia during induction treatment: setting the stage for anti-CD20 directed immunotherapy. Blood 112, 3982-3988.

Edelbauer, M., Datta, D., Vos, I. H., Basu, A., Stack, M. P., Reinders, M. E., Sho, M., Calzadilla, K., Ganz, P. and Briscoe, D. M. (2010). Effect of vascular endothelial growth factor and its receptor $\mathrm{KDR}$ on the transendothelial migration and local trafficking of human T cells in vitro and in vivo. Blood 116, 1980-1989.

Evens, A. M., Roy, R., Sterrenberg, D., Moll, M. Z., Chadburn, A., and Gordon, L. I. (2010). Posttransplantation lymphoproliferative disorders: diagnosis, prognosis, and current approaches to therapy. Curr. Oncol. Rep. 12, 383-394.

Falini, B., Pulford, K., Pucciarini, A., Carbone, A., De Wolf-Peeters, C. Cordell, J., Fizzotti, M., Santucci, A., Pelicci, P. G., Pileri, S., Campo, E., Ott, G., Delsol, G., and Mason, D. Y. (1999). Lymphomas expressing ALK fusion protein(s) other than NPM-ALK. Blood 94, 3509-3515.

Fichtner-Feigl, S., Strober, W., Kawakami, K., Puri, R. K., and Kitani, A. (2006). IL-13 signaling through the IL-13alpha2 receptor is involved in induction of TGF-beta1 production and fibrosis. Nat. Med. 12, 99-106

Flynn, J. M., and Byrd, J. C. (2000). Campath-1H monoclonal antibody therapy. Curr. Opin. Oncol. 12, 574-581.

Foell, J. L., Hesse, M., Volkmer, I., Schmiedel, B. J., Neumann, I., and Staege, M. S. (2008). Membraneassociated phospholipase Al beta (LIPI) Is an Ewing tumourassociated cancer/testis antigen. Pediatr. Blood Cancer 51, 228-234.

Forero-Torres, A., Leonard, J. P., Younes, A., Rosenblatt, J. D., Brice, P., Bartlett, N. L., Bosly, A., PinterBrown, L., Kennedy, D., Sievers, E. L., and Gopal, A. K. (2009). A phase II study of SGN-30 (anti-CD30 mAb) in Hodgkin lymphoma or systemic anaplastic large cell lymphoma. $\mathrm{Br}$. J. Haematol. 146, 171-179.

Fratta, E., Coral, S., Covre, A., Parisi, G., Colizzi, F., Danielli, R., Marie Nicolay, H. J., Sigalotti, L., and Maio, M. (2011). The biology of cancer testis antigens: putative function, regulation and therapeutic potential. $\mathrm{Mol}$ Oncol 5, 164-182. 
Furman, R. R., Grossbard, M. L., Johnson, J. L., Pecora, A. L., Cassileth, P. A., Jung, S. H., Peterson, B. A., Nadler, L. M., Freedman, A., Bayer, R. L., Bartlett, N. L., Hurd, D. D., Cheson, B. D., Cancer Leukemia Group B, and Eastern Cooperative Oncology Group. (2011). A phase III study of anti-B4-blocked ricin as adjuvant therapy post-autologous bone marrow transplant: CALGB 9254. Leuk. Lymphoma 52, 587-596.

Gaipa, G., Basso, G., Maglia, O., Leoni, V., Faini, A., Cazzaniga, G., Bugarin, C., Veltroni, M., Michelotto, B., Ratei, R., Coliva, T., Valsecchi, M. G., Biondi, A., Dworzak, M. N., and I-BFM-ALL-FCM-MRD Study Group. (2005). Drug-induced immunophenotypic modulation in childhood ALL: implications for minimal residual disease detection. Leukemia 19, 49-56.

Gambacorti-Passerini, C., Grignani, F., Arienti, F., Pandolfi, P. P., Pelicci, P. G., and Parmiani, G. (1993). Human CD4 lymphocytes specifically recognize a peptide representing the fusion region of the hybrid protein PML/RAR alpha present in acute promyelocytic leukemia cells. Blood 81, 1369-1375.

Garin-Chesa, P., Campbell, I., Saigo, P. E., Lewis, J. L. Jr., Old, L. J., and Rettig, W. J. (1993). Trophoblast and ovarian cancer antigen LK26. Sensitivity and specificity in immunopathology and molecular identification as a folate-binding protein. Am. J. Pathol. 142, 557-567.

George, R. E., Sanda, T., Hanna, M., Fröhling, S., Luther W, 2. n. d., Zhang, J., Ahn, Y., Zhou, W., London, W. B., McGrady, P., Xue, L., Zozulya, S., Gregor, V. E., Webb, T. R., Gray, N. S., Gilliland, D. G., Diller, L., Greulich, H., Morris, S. W., Meyerson, M., and Look, A. T. (2008). Activating mutations in ALK provide a therapeutic target in neuroblastoma. Nature 455, 975-978.

Gilbertson, R. J. (2005). ERBB2 in pediatric cancer: innocent until proven guilty. Oncologist 10, 508-517.

Gogas, H., Ioannovich, J., Dafni, U., Stavropoulou-Giokas, C., Frangia, K., Tsoutsos, D., Panagiotou, P., Polyzos, A., Papadopoulos, O., Stratigos, A., Markopoulos, C., Bafaloukos, D., Pectasides, D., Fountzilas, G., and Kirkwood, J. M. (2006). Prognostic significance of autoimmunity during treatment of melanoma with interferon. N. Engl. J. Med. 354, 709-718.

Gonzalez-Angulo, A. M., Hortobagyi, G. N., and Esteva, F. J. (2006). Adjuvant therapy with trastuzumab for
HER-2/neu-positive breast cancer. Oncologist 11, 857-867.

Gorlick, R., Huvos, A. G., Heller, G., Aledo, A., Beardsley, G. P., Healey, J. H., and Meyers, P. A. (1999). Expression of HER2/erbB-2 correlates with survival in osteosarcoma. J. Clin. Oncol. 17, 2781-2788.

Grau, E., Oltra, S., Martinez, F., Orellana, C., Cañete, A., Fernández, J. M., Hernández-Martí, M., and Castel, V. (2009). MAGE-A1 expression is associated with good prognosis in neuroblastoma tumors. J. Cancer Res. Clin. Oncol. 135, 523-531.

Greiner, J., Ringhoffer, M., Taniguchi, M., Hauser, T., Schmitt, A., Döhner, H., and Schmitt, M. (2003). Characterization of several leukemia-associated antigens inducing humoral immune responses in acute and chronic myeloid leukemia. Int. J. Cancer 106, 224-231.

Greiner, J., Ringhoffer, M., Taniguchi, M., Schmitt, A., Kirchner, D., Krähn, G., Heilmann, V., Gschwend, J., Bergmann, L., Döhner, H., and Schmitt, M. (2002). Receptor for hyaluronan acid-mediated motility (RHAMM) is a new immunogenic leukemia-associated antigen in acute and chronic myeloid leukemia. Exp. Hematol. 30, 1029-1035.

Griffin, T. C., Weitzman, S., Weinstein, H., Chang, M., Cairo, M., Hutchison, R., Shiramizu, B., Wiley, J., Woods, D., Barnich, M., Gross, T. G., and Children's Oncology Group. (2009). A study of rituximab and ifosfamide, carboplatin, and etoposide chemotherapy in children with recurrent/refractory B-cell (CD20+) non-Hodgkin lymphoma and mature B-cell acute lymphoblastic leukemia: a report from the Children's Oncology Group. Pediatr. Blood Cancer 52, 177-181.

Grzelinski, M., Steinberg, F., Martens, T., Czubayko, F., Lamszus, K., and Aigner, A. (2009). Enhanced antitumorigenic effects in glioblastoma on double targeting of pleiotrophin and its receptor ALK. Neoplasia 11, 145-156.

Gudowius, S., Recker, K., Laws, H. J., Dirksen, U., Tröger, A., Wieczorek, U., Furlan, S., Göbel, U., and Hanenberg, H. (2006). Identification of candidate target antigens for antibody-based immunotherapy in childhood B-cell precursor ALL. Klin. Padiatr. 218, 327-333.

Hamilton, W. B., Helling, F., Lloyd, K. O., and Livingston, P. O. (1993). Ganglioside expression on human malignant melanoma assessed by quantitative immune thin-layer chromatography. Int. J. Cancer 53, 566-573.

Harvey, R. C., Mullighan, C. G., Chen, I. M., Wharton, W., Mikhail, F. M., Carroll, A. J., Kang, H., Liu, W., Dobbin, K. K., Smith, M. A. Carroll, W. L., Devidas, M., Bowman, W. P., Camitta, B. M., Reaman, G. H., Hunger, S. P., Downing, J. R., and Willman, C. L. (2010). Rearrangement of CRLF2 is associated with mutation of JAK kinases, alteration of IKZF1, hispanic/latino ethnicity, and a poor outcome in pediatric B-progenitor acute lymphoblastic leukemia. Blood 115, 5312-5321.

Hecker, M., Zaslona, Z., Kwapiszewska, G., Niess, G., Zakrzewicz, A., Hergenreider, E., Wilhelm, J., Marsh, L. M., Sedding, D., Klepetko, W., Lohmeyer, J., Dimmeler, S., Seeger, W., Weissmann, N., Schermuly, R. T., Kneidinger, N., Eickelberg, O., and Morty, R. E. (2010). Dysregulation of the IL-13 receptor system: a novel pathomechanism in pulmonary arterial hypertension. Am. J. Respir. Crit. Care Med. 182, 805-818.

Heimberger, A. B., Hlatky, R., Suki, D., Yang, D., Weinberg, J., Gilbert, M., Sawaya, R., and Aldape, K. (2005). Prognostic effect of epidermal growth factor receptor and EGFRvIII in glioblastoma multiforme patients. Clin. Cancer Res. 11, 1462-1466.

Herbst, H., Raff, T., and Stein, H. (1996). Phenotypic modulation of Hodgkin and Reed-Sternberg cells by EpsteinBarr virus. J. Pathol. 179, 54-59.

Herrera, L., Bostrom, B., Gore, L., Sandler, E., Lew, G., Schlegel, P. G., Aquino, V., Ghetie, V., Vitetta, E. S., and Schindler, J. (2009). A phase 1 study of Combotox in pediatric patients with refractory B-lineage acute lymphoblastic leukemia. J. Pediatr. Hematol. Oncol. 31, 936-941.

Hubert, R. S., Vivanco, I., Chen, E. Rastegar, S., Leong, K., Mitchell, S. C., Madraswala, R., Zhou, Y., Kuo, J., Raitano, A. B., Jakobovits, A., Saffran, D. C., and Afar, D. E. (1999). STEAP: a prostate-specific cellsurface antigen highly expressed in human prostate tumors. Proc. Natl. Acad. Sci. U.S.A. 96, 14523-14528.

Hudecek, M., Schmitt, T. M., Baskar, S., Lupo-Stanghellini, M. T., Nishida, T., Yamamoto, T. N., Bleakley, M., Turtle, C. J., Chang, W. C., Greisman, H. A., Wood, B., Maloney, D. G., Jensen, M. C., Rader, C., and Riddell, S. R. (2010). The Bcell tumor-associated antigen ROR1 can be targeted with $\mathrm{T}$ cells modified to express a ROR1-specific chimeric antigen receptor. Blood 116, 4532-4541.

Hughes, D. P., Thomas, D. G., Giordano, T. J., Baker, L. H., and McDonagh, K. T. (2004). Cell surface expression of epidermal growth factor receptor and Her-2 with nuclear expression of Her-4 in primary osteosarcoma. Cancer Res. 64, 2047-2053.

Hu-Lieskovan, S., Zhang, J., Wu, L., Shimada, H., Schofield, D. E., and Triche, T. J. (2005). EWS-FLI1 fusion protein up-regulates critical genes in neural crest development and is responsible for the observed phenotype of Ewing's family of tumors. Cancer Res. 65, 4633-4644.

Inoue, K., Ogawa, H., Sonoda, Y., Kimura, T., Sakabe, H., Oka, Y., Miyake, S., Tamaki, H., Oji, Y., Yamagami, T., Tatekawa, T., Soma, T., Kishimoto, T., and Sugiyama, H. (1997). Aberrant overexpression of the Wilms tumor gene (WT1) in human leukemia. Blood 89, 1405-1412.

Jacobs, J. F., Brasseur, F., Hulsbergen-van de Kaa, C. A., van de Rakt, M. W., Figdor, C. G., Adema, G. J., Hoogerbrugge, P. M., Coulie, P. G., and de Vries, I. J. (2007). Cancer-germline gene expression in pediatric solid tumors using quantitative real-time PCR. Int. J. Cancer 120, 67-74.

Jacobs, J. F., Grauer, O. M., Brasseur, F., Hoogerbrugge, P. M., Wesseling, P., Gidding, C. E., van de Rakt, M. W., Figdor, C. G., Coulie, P. G., de Vries, I. J., and Adema, G. J. (2008). Selective cancer-germline gene expression in pediatric brain tumors. $J$. Neurooncol. 88, 273-280.

James, S. E., Greenberg, P. D., Jensen, M. C., Lin, Y., Wang, J., Till, B. G., Raubitschek, A. A., Forman, S. J., and Press, O. W. (2008). Antigen sensitivity of CD22-specific chimeric TCR is modulated by target epitope distance from the cell membrane. J. Immunol. 180, 7028-7038.

Jeha, S., Behm, F., Pei, D., Sandlund, J. T., Ribeiro, R. C., Razzouk, B. I., Rubnitz, J. E., Hijiya, N., Howard, S. C., Cheng, C., and Pui, C. H. (2006). Prognostic significance of CD20 expression in childhood Bcell precursor acute lymphoblastic leukemia. Blood 108, 3302-3304.

Jin, H. J., Nam, H. Y., Bae, Y. K., Kim, S. Y., Im, I. R., Oh, W., Yang, Y. S., Choi, S. J., and Kim, S. W. (2006). GD2 expression is closely associated with neuronal differentiation of human umbilical cord blood-derived mesenchymal stem cells. Cell. Mol. Life Sci. 67, 1845-1858. 
Jungbluth, A. A., Antonescu, C. R., Busam, K. J., Iversen, K., Kolb, D., Coplan, K., Chen, Y. T., Stockert, E., Ladanyi, M., and Old, L. J. (2001). Monophasic and biphasic synovial sarcomas abundantly express cancer/testis antigen NY-ESO-1 but not MAGE-A1 or CT7. Int. J. Cancer 94, 252-256.

Junker, K., Hindermann, W., von Eggeling, F., Diegmann, J., Haessler, K., and Schubert, J. (2005). CD70: a new tumor specific biomarker for renal cell carcinoma. J. Urol. 173, 2150-2153.

Kahlon, K. S., Brown, C., Cooper, L. J., Raubitschek, A., Forman, S. J., and Jensen, M. C. (2004). Specific recognition and killing of glioblastoma multiforme by interleukin 13-zetakine redirected cytolytic T cells. Cancer Res. 64, 9160-9166.

Kalos, M., Levine, B. L., Porter, D. L., Katz, S., Grupp, S. A., Bagg, A., and June, C. H. (2011). T cells with chimeric antigen receptors have potent antitumor effects and can establish memory in patients with advanced leukemia. Sci. Transl. Med. 3, $95 \mathrm{ra73.}$

Kasaian, M. T., Raible, D., Marquette, K., Cook, T. A., Zhou, S., Tan, X. Y., and Tchistiakova, L. (2011). IL13 antibodies influence IL-13 clearance in humans by modulating scavenger activity of IL-13Ralpha2. J. Immunol. 187, 561-569.

Kasuga, C., Nakahara, Y., Ueda, S., Hawkins, C., Taylor, M. D., Smith, C. A., and Rutka, J. T. (2008). Expression of MAGE and GAGE genes in medulloblastoma and modulation of resistance to chemotherapy. Laboratory investigation. J. Neurosurg. Pediatr. 1, 305-313.

Kawakami, K., Terabe, M., Kawakami, M., Berzofsky, J. A., and Puri, R. K. (2006). Characterization of a novel human tumor antigen interleukin13 receptor alpha 2 chain. Cancer Res. 66, 4434-4442.

Kennedy, M. K., Willis, C. R., and Armitage, R. J. (2006). Deciphering CD30 ligand biology and its role in humoral immunity. Immunology 118, 143-152.

Kershaw, M. H., Westwood, J. A., Parker, L. L., Wang, G., Eshhar, Z., Mavroukakis, S. A., White, D. E., Wunderlich, J. R., Canevari, S., Rogers-Freezer, L., Chen, C. C., Yang, J. C., Rosenberg, S. A., and Hwu, P. (2006). A phase I study on adoptive immunotherapy using gene-modified $\mathrm{T}$ cells for ovarian cancer. Clin. Cancer Res. 12, 6106-6115.
Kioi, M., Seetharam, S., and Puri, R. K. (2008). Targeting IL-13Ralpha2positive cancer with a novel recombinant immunotoxin composed of a single-chain antibody and mutated Pseudomonas exotoxin. Mol. Cancer Ther. 7, 1579-1587.

Kochenderfer, J. N., Wilson, W. H., Janik, J. E., Dudley, M. E., StetlerStevenson, M., Feldman, S. A., Maric, I., Raffeld, M., Nathan, D. A., Lanier, B. J., Morgan, R. A., and Rosenberg, S. A. (2010). Eradication of Blineage cells and regression of lymphoma in a patient treated with autologous $\mathrm{T}$ cells genetically engineered to recognize CD19. Blood 116, 4099-4102.

Konner, J. A., Bell-McGuinn, K. M., Sabbatini, P., Hensley, M. L., Tew, W. P., Pandit-Taskar, N., Vander Els, N., Phillips, M. D., Schweizer, C., Weil, S. C., Larson, S. M., and Old, L. J. (2010). Farletuzumab, a humanized monoclonal antibody against folate receptor alpha, in epithelial ovarian cancer: a phase I study. Clin. Cancer Res. 16, 5288-5295.

Kumar, R., Galardy, P. J., Dogan, A., Rodriguez, V., Khan, S. P. (2011). Rituximab in combination with multi agent chemotherapy for pediatric follicular lymphoma. Pediatr. Blood Cancer 57, 317-320.

Kunwar, S., Chang, S., Westphal, M., Vogelbaum, M., Sampson, J., Barnett, G., Shaffrey, M., Ram, Z., Piepmeier, J., Prados, M., Croteau, D., Pedain, C., Leland, P., Husain, S. R., Joshi, B. H., Puri, R. K., and PRECISE Study Group. (2010). Phase III randomized trial of CED of IL13PE38QQR vs. Gliadel wafers for recurrent glioblastoma. Neurooncology 12, 871-881.

Kushner, B. H., Kramer, K., Modak, S., and Cheung, N. K. (2011). Successful multifold dose escalation of anti-GD2 monoclonal antibody $3 F 8$ in patients with neuroblastoma: a phase I study. J. Clin. Oncol. 29, 1168-1174.

Law, C. L., Gordon, K. A., Toki, B. E., Yamane, A. K., Hering, M. A., Cerveny, C. G., Petroziello, J. M., Ryan, M. C., Smith, L., Simon, R., Sauter, G., Oflazoglu, E., Doronina, S. O., Meyer, D. L., Francisco, J. A., Carter, P., Senter, P. D., Copland, J. A., Wood, C. G., and Wahl, A. F. (2006). Lymphocyte activation antigen CD70 expressed by renal cell carcinoma is a potential therapeutic target for anti-CD70 antibodydrug conjugates. Cancer Res. 66, 2328-2337.

Leah, E. (2011). Therapy: rituximab for refractory SLE-patients reach lasting remission with short-term regimen. Nat. Rev. Rheumatol. 7, 312.

Leisegang, M., Wilde, S., Spranger, S., Milosevic, S., Frankenberger, B. Uckert, W., and Schendel, D. J. (2010). MHC-restricted fratricide of human lymphocytes expressing survivin-specific transgenic $\mathrm{T}$ cell receptors. J. Clin. Invest. 120, 3869-3877.

Lens, S. M., Drillenburg, P., den Drijver, B. F., van Schijndel, G., Pals, S. T., van Lier, R. A., and van Oers, M. H. (1999). Aberrant expression and reverse signalling of CD70 on malignant B cells. Br. J. Haematol. 106 491-503.

Leoncini, L., Del Vecchio, M. T., Kraft, R., Megha, T., Barbini, P., Cevenini, G., Poggi, S., Pileri, S., Tosi, P., and Cottier, H. (1990). Hodgkin's disease and CD30-positive anaplastic large cell lymphomas - a continuous spectrum of malignant disorders. A quantitative morphometric and immunohistologic study. Am. J. Pathol. 137, 1047-1057.

Liu, X. F., Helman, L. J., Yeung, C., Bera, T. K., Lee, B., and Pastan, I. (2000). XAGE-1, a new gene that is frequently expressed in Ewing's sarcoma. Cancer Res. 60, 4752-4755.

Lo, A. S., Ma, Q., Liu, D. L., and Junghans, R. P. (2010). Anti-GD3 chimeric sFv-CD28/T-cell receptor zeta designer $\mathrm{T}$ cells for treatment of metastatic melanoma and other neuroectodermal tumors. Clin. Cancer Res. 16, 2769-2780.

Louis, C. U., Savoldo, B., Dotti, G., Pule, M., Yvon, E., Myers, G. D., Rossig, C., Russell, H. V., Diouf, O., Liu, E., Liu, H., Wu, M. F., Gee, A. P., Mei, Z., Rooney, C. M., Heslop, H. E., and Brenner, M. K. (2011). Antitumor activity and long-term fate of chimeric antigen receptor-positive $\mathrm{T}$ cells in patients with neuroblastoma. Blood 118, 6050-6056.

Lucio, P., Gaipa, G., van Lochem, E. G., van Wering, E. R., PorwitMacDonald, A., Faria, T., Bjorklund, E., Biondi, A., van den Beemd, M. W., Baars, E., Vidriales, B., Parreira, A., van Dongen, J. J., San Miguel, J. F., Orfao, A., and BIOMEDI. (2001). BIOMED-I concerted action report: flow cytometric immunophenotyping of precursor B-ALL with standardized triple-stainings. BIOMED1 concerted action investigation of minimal residual disease in acute leukemia: international standardization and clinical evaluation. Leukemia 15, 1185-1192.

Luiten, R. M., Kueter, E. W., Mooi, W., Gallee, M. P., Rankin, E. M., Gerritsen, W. R., Clift, S. M., Nooijen, W.
J., Weder, P., van de Kasteele, W. F., Sein, J., van den Berk, P. C., Nieweg, O. E., Berns, A. M., Spits, H., and de Gast, G. C. (2005). Immunogenicity, including vitiligo, and feasibility of vaccination with autologous GM-CSF-transduced tumor cells in metastatic melanoma patients. J. Clin. Oncol. 23, 8978-8991.

Majeti, R., Chao, M. P., Alizadeh, A. A., Pang, W. W., Jaiswal, S., Gibbs, K. D. Jr., van Rooijen, N., and Weissman, I. L. (2009). CD47 is an adverse prognostic factor and therapeutic antibody target on human acute myeloid leukemia stem cells. Cell 138, 286-299.

Matutes, E., Rodriguez, B., Polli, N., Tavares de Castro, J., Parreira, A., Andrews, C., Griffin, J. D., Tindle, R. W., and Catovsky, D. (1985). Characterization of myeloid leukemias with monoclonal antibodies 3C5 and MY9. Hematol. Oncol. 3, 179-186.

Meinhardt, A., Burkhardt, B., Zimmermann, M., Borkhardt, A., Kontny, U., Klingebiel, T., Berthold, F., JankaSchaub, G., Klein, C., Kabickova, E., Klapper, W., Attarbaschi, A., Schrappe, M., Reiter, A., and BerlinFrankfurt-Münster Group. (2010). Phase II window study on rituximab in newly diagnosed pediatric mature B-cell non-Hodgkin's lymphoma and Burkitt leukemia. J. Clin. Oncol. 28, 3115-3121.

Modak, S., Gerald, W., and Cheung, N. K. (2002). Disialoganglioside GD2 and a novel tumor antigen: potential targets for immunotherapy of desmoplastic small round cell tumor. Med. Pediatr. Oncol. 39, 547-551.

Modak, S., Kramer, K., Gultekin, S. H., Guo, H. F., and Cheung, N. K. (2001). Monoclonal antibody 8H9 targets a novel cell surface antigen expressed by a wide spectrum of human solid tumors. Cancer Res. 61, 4048-4054.

Molldrem, J., Dermime, S., Parker, K., Jiang, Y. Z., Mavroudis, D., Hensel, N., Fukushima, P., and Barrett, A. J. (1996). Targeted T-cell therapy for human leukemia: cytotoxic $\mathrm{T}$ lymphocytes specific for a peptide derived from proteinase 3 preferentially lyse human myeloid leukemia cells. Blood 88, 2450-2457.

Moog-Lutz, C., Degoutin, J., Gouzi, J. Y., Frobert, Y., Brunet-de Carvalho, N., Bureau, J., Créminon, C., and Vigny, M. (2005). Activation and inhibition of anaplastic lymphoma kinase receptor tyrosine kinase by monoclonal antibodies and absence of agonist activity of pleiotrophin. J. Biol. Chem. 280, 26039-26048. 
Morgan, R. A., Yang, J. C., Kitano, M., Dudley, M. E., Laurencot, C. M., and Rosenberg, S. A. (2010). Case report of a serious adverse event following the administration of $\mathrm{T}$ cells transduced with a chimeric antigen receptor recognizing ERBB2. Mol. Ther. 18, 843-851.

Mosse, Y. P., Laudenslager, M., Longo, L., Cole, K. A., Wood, A., Attiyeh, E. F., Laquaglia, M. J., Sennett, R., Lynch, J. E., Perri, P., Laureys, G., Speleman, F., Kim, C., Hou, C., Hakonarson, H., Torkamani, A., Schork, N. J., Brodeur, G. M., Tonini, G. P., Rappaport, E., Devoto, M., and Maris, J. M. (2008). Identification of ALK as a major familial neuroblastoma predisposition gene. Nature 455, 930-935.

Mulens, V., de la Torre, A., Marinello, P., Rodríguez, R., Cardoso, J., Díaz, R., O’Farrill, M., Macias, A., Viada, C., Saurez, G., Carr, A., Crombet, T., Mazorra, Z., Perez, R., and Fernandez, L. E. (2010). Immunogenicity and safety of a NeuGcGM3 based cancer vaccine: results from a controlled study in metastatic breast cancer patients. Hum. Vaccin. 6, 736-744.

Nadler, L. M., Anderson, K. C., Marti, G., Bates, M., Park, E., Daley, J. F., and Schlossman, S. F. (1983). B4, a human B lymphocyteassociated antigen expressed on normal, mitogen-activated, and malignant B lymphocytes. J. Immunol. 131, 244-250.

Nadler, L. M., Korsmeyer, S. J., Anderson, K. C., Boyd, A. W., Slaughenhoupt, B., Park, E., Jensen, J., Coral, F., Mayer, R. J., Sallan, S. E., Jerome, Ritz., and Schlossman, S. F. (1984). B cell origin of non-T cell acute lymphoblastic leukemia. A model for discrete stages of neoplastic and normal pre-B cell differentiation. J. Clin. Invest. 74, 332-340.

Nakatsuka, S., Oji, Y., Horiuchi, T., Kanda, T., Kitagawa, M., Takeuchi, T., Kawano, K., Kuwae, Y., Yamauchi, A., Okumura, M., Kitamura, Y., Oka, Y., Kawase, I., Sugiyama, H., and Aozasa, K. (2006). Immunohistochemical detection of WT1 protein in a variety of cancer cells. Mod. Pathol. 19, 804-814.

Nakatsura, T., Kageshita, T., Ito, S., Wakamatsu, K., Monji, M., Ikuta, Y., Senju, S., Ono, T., and Nishimura, Y. (2004). Identification of glypican3 as a novel tumor marker for melanoma. Clin. Cancer Res. 10, 6612-6621.

Navid, F., Santana, V. M., and Barfield, R. C. (2010). Anti-GD2 antibody therapy for GD2-expressing tumors.
Curr. Cancer Drug Targets 10, 200-209.

Normanno, N., Tejpar, S., Morgillo, F., De Luca, A., Van Cutsem, E., and Ciardiello, F. (2009). Implications for KRAS status and EGFR-targeted therapies in metastatic CRC. Nat. Rev. Clin. Oncol. 6, 519-527.

Oba-Shinjo, S. M., Caballero, O. L., Jungbluth, A. A., Rosemberg, S., Old, L. J., Simpson, A. J., and Marie, S. K. (2008). Cancer-testis (CT) antigen expression in medulloblastoma. Cancer Immun. 8, 7.

Oberthuer, A., Hero, B., Spitz, R., Berthold, F., and Fischer, M. (2004). The tumor-associated antigen PRAME is universally expressed in high-stage neuroblastoma and associated with poor outcome. Clin. Cancer Res. 10, 4307-4313.

Ohmi, Y., Tajima, O., Ohkawa, Y., Yamauchi, Y., Sugiura, Y., and Furukawa, K. (2011). Gangliosides are essential in the protection of inflammation and neurodegeneration via maintenance of lipid rafts: elucidation by a series of ganglioside-deficient mutant mice. J. Neurochem. 116, 926-935.

Ohno, M., Natsume, A., Ichiro Iwami, K., Iwamizu, H., Noritake, K., Ito, D., Toi, Y., Ito, M., Motomura, K., Yoshida, J., Yoshikawa, K., and Wakabayashi, T. (2010). Retrovirally engineered T-cell-based immunotherapy targeting type III variant epidermal growth factor receptor, a glioma-associated antigen. Cancer Sci. 101, 2518-2524.

Ohta, H., Hashii, Y., Yoneda, A., Takizawa, S., Kusuki, S., Tokimasa, S., Fukuzawa, M., Tsuboi, A., Murao, A., Oka, Y., Oji, Y., Aozasa, K., Nakatsuka, S., Sugiyama, H., and Ozono, K. (2009). WT1 (Wilms tumor 1) peptide immunotherapy for childhood rhabdomyosarcoma: a case report. Pediatr. Hematol. Oncol. 26, 74-83.

Olsen, S. K., Garbi, M., Zampieri, N., Eliseenkova, A. V., Ornitz, D. M., Goldfarb, M., and Mohammadi, M. (2003). Fibroblast growth factor (FGF) homologous factors share structural but not functional homology with FGFs. J. Biol. Chem. 278, 34226-34236.

Oshima, Y., Joshi, B. H., and Puri, R. K. (2000). Conversion of interleukin13 into a high affinity agonist by a single amino acid substitution. J. Biol. Chem. 275, 14375-14380.

Park, J. R., Digiusto, D. L., Slovak, M., Wright, C., Naranjo, A., Wagner, J., Meechoovet, H. B., Bautista, C., Chang, W. C., Ostberg, J. R., and Jensen, M. C. (2007). Adoptive transfer of chimeric antigen receptor re-directed cytolytic $\mathrm{T}$ lymphocyte clones in patients with neuroblastoma. Mol. Ther. 15, 825-833.

Pastor, F., Kolonias, D., McNamara Ii, J. O. II., Gilboa, E. (2011). Targeting 4-1BB costimulation to disseminated tumor lesions with bi-specific oligonucleotide aptamers. Mol Ther. 19, 1878-1886.

Paulson, V., Chandler, G., Rakheja, D., Galindo, R. L., Wilson, K. Amatruda, J. F., and Cameron, S. (2011). High-resolution array CGH identifies common mechanisms that drive embryonal rhabdomyosarcoma pathogenesis. Genes Chromosomes Cancer 50, 397-408.

Peggs, K. S., Quezada, S. A., Korman, A. J., and Allison, J. P. (2006). Principles and use of anti-CTLA4 antibody in human cancer immunotherapy. Curr. Opin. Immunol. 18, 206-213.

Piccaluga, P. P., Arpinati, M., Candoni, A., Laterza, C., Paolini, S., Gazzola, A., Sabattini, E., Visani, G., and Pileri, S. A. (2010). Surface antigens analysis reveals significant expression of candidate targets for immunotherapy in adult acute lymphoid leukemia. Leuk. Lymphoma 52, 325-327.

Pollack, S. M., Loggers, E. T., Rodler, E. T., Yee, C., and Jones, R. L. (2011). Immune-based therapies for sarcoma. Sarcoma 2011, 438940.

Porter, D. L., Levine, B. L., Kalos, M., Bagg, A., and June, C. H. (2011). Chimeric antigen receptormodified $\mathrm{T}$ cells in chronic lymphoid leukemia. N. Engl. J. Med. 365, 725-733.

Pule, M. A., Savoldo, B., Myers, G. D., Rossig, C., Russell, H. V., Dotti, G., Huls, M. H., Liu, E., Gee, A. P., Mei, Z., Yvon, E., Weiss, H. L., Liu, H., Rooney, C. M., Heslop, H. E., and Brenner, M. K. (2008). Virus-specific $\mathrm{T}$ cells engineered to coexpress tumor-specific receptors: persistence and antitumor activity in individuals with neuroblastoma. Nat. Med. 14, 1264-1270.

Pulford, K., Lamant, L., Morris, S. W., Butler, L. H., Wood, K. M., Stroud, D., Delsol, G., and Mason, D. Y. (1997). Detection of anaplastic lymphoma kinase (ALK) and nucleolar protein nucleophosmin (NPM)-ALK proteins in normal and neoplastic cells with the monoclonal antibody ALK1. Blood 89, 1394-1404

Raetz, E. A., Cairo, M. S., Borowitz, M. J., Blaney, S. M., Krailo, M. D., Leil, T. A., Reid, J. M., Goldenberg, D. M., Wegener, W. A., Carroll, W. L., Adamson, P. C., and
Children's Oncology Group Pilot Study. (2008). Chemoimmunotherapy reinduction with epratuzumab in children with acute lymphoblastic leukemia in marrow relapse: a Children's Oncology Group Pilot Study. J. Clin. Oncol. 26, 3756-3762.

Ragab, S. M., Samaka, R. M., and Shams, T. M. (2010). HER $2 /$ neu expression: a predictor for differentiation and survival in children with Wilms tumor. Pathol. Oncol. Res. 16, 61-67.

Rapoport, A. P., Aqui, N. A., Stadtmauer, E. A., Vogl, D. T., Fang, H. B., Cai, L., Janofsky, S., Chew, A., Storek, J., Akpek, G., Badros, A., Yanovich, S., Tan, M. T., Veloso, E., Pasetti, M. F., Cross, A., Philip, S., Murphy, H., Bhagat, R., Zheng, Z., Milliron, T., Cotte, J., Cannon, A., Levine, B. L., Vonderheide, R. H., and June, C. H. (2011). Combination immunotherapy using adoptive T-cell transfer and tumor antigen vaccination on the basis of hTERT and survivin after ASCT for myeloma. Blood 117, 788-797.

Ravindranath, M. H., Yesowitch, P., Sumobay, C., and Morton, D. L. (2007). Glycoimmunomics of human cancer: current concepts and future perspectives. Future. Oncol. 3, 201-214.

Rezvani, K. (2008). PR1 vaccination in myeloid malignancies. Expert Rev. Vaccines 7, 867-875.

Ribas, A., and Flaherty, K. T. (2011). BRAF targeted therapy changes the treatment paradigm in melanoma. Nat. Rev. Clin. Oncol. 8, 426-433.

Robbins, P. F., Morgan, R. A., Feldman, S. A., Yang, J. C., Sherry, R. M., Dudley, M. E., Wunderlich, J. R., Nahvi, A. V., Helman, L. J., Mackall, C. L., Kammula, U. S., Hughes, M. S., Restifo, N. P., Raffeld, M., Lee, C. C., Levy, C. L., Li, Y. F., El-Gamil, M., Schwarz, S. L., Laurencot, C., and Rosenberg, S. A. (2011). Tumor regression in patients with metastatic synovial cell sarcoma and melanoma using genetically engineered lymphocytes reactive with NY-ESO-1. J. Clin. Oncol. 29, 917-924.

Rosenfeld, C., Cheever, M. A., and Gaiger, A. (2003). WT1 in acute leukemia, chronic myelogenous leukemia and myelodysplastic syndrome: therapeutic potential of WT1 targeted therapies. Leukemia 17, 1301-1312.

Ross, J. F., Chaudhuri, P. K., and Ratnam, M. (1994). Differential regulation of folate receptor isoforms in normal and malignant tissues in vivo and in established cell lines. Physiologic 
and clinical implications. Cancer 73, 2432-2443.

Russell, L. J., Capasso, M., Vater, I., Akasaka, T., Bernard, O. A., Calasanz, M. J., Chandrasekaran, T., Chapiro, E., Gesk, S., Griffiths, M., Guttery, D. S., Haferlach, C., Harder, L., Heidenreich, O., Irving, J., Kearney, L., Nguyen-Khac, F., Machado, L., Minto, L., Majid, A., Moorman, A. V., Morrison, H., Rand, V., Strefford, J. C., Schwab, C., Tönnies, H., Dyer, M. J., Siebert, R., and Harrison, C. J. (2009). Deregulated expression of cytokine receptor gene, CRLF2, is involved in lymphoid transformation in B-cell precursor acute lymphoblastic leukemia. Blood 114, 2688-2698.

Saikali, Z., and Sinnett, D. (2000). Expression of glypican 3 (GPC3) in embryonal tumors. Int. J. Cancer 89, 418-422.

Sampson, J. H., Heimberger, A. B., Archer, G. E., Aldape, K. D., Friedman, A. H., Friedman, H. S., Gilbert, M. R., Herndon, J. E. II., McLendon, R. E., Mitchell, D. A., Reardon, D. A., Sawaya, R., Schmittling, R. J., Shi, W., Vredenburgh, J. J., and Bigner, D. D. (2010). Immunologic escape after prolonged progression-free survival with epidermal growth factor receptor variant III peptide vaccination in patients with newly diagnosed glioblastoma. J. Clin. Oncol. 28, 4722-4729.

Schindler, J., Gajavelli, S., Ravandi, F., Shen, Y., Parekh, S., Braunchweig, I., Barta, S., Ghetie, V., Vitetta, E., and Verma, A. (2011). A phase I study of a combination of antiCD19 and anti-CD22 immunotoxins (Combotox) in adult patients with refractory B-lineage acute lymphoblastic leukaemia. Br. J. Haematol. 154, 471-476.

Schulz, G., Cheresh, D. A., Varki, N. M., Yu, A., Staffileno, L. K., and Reisfeld, R. A. (1984). Detection of ganglioside GD2 in tumor tissues and sera of neuroblastoma patients. Cancer Res. 44, 5914-5920.

Scursoni, A. M., Galluzzo, L., Camarero, S., Pozzo, N., Gabri, M. R., de Acosta, C. M., Vázquez, A. M., Alonso, D. F., and de Dávila, M. T. (2010). Detection and characterization of $N$-glycolyated gangliosides in Wilms tumor by immunohistochemistry. Pediatr. Dev. Pathol. 13, 18-23.

Segal, N. H., Blachere, N. E., GuevaraPatino, J. A., Gallardo, H. F., Shiu, H. Y., Viale, A., Antonescu, C. R., Wolchok, J. D., and Houghton, A. N. (2005). Identification of cancertestis genes expressed by melanoma and soft tissue sarcoma using bioinformatics. Cancer Immun. 5, 2.

Segal, N. H., Parsons, D. W., Peggs, K. S., Velculescu, V., Kinzler, K. W., Vogelstein, B., and Allison, J. P. (2008). Epitope landscape in breast and colorectal cancer. Cancer Res. 68, 889-892.

Shaffer, D. R., Savoldo, B., Yi, Z., Chow, K. K., Kakarla, S., Spencer, D. M., Dotti, G., Wu, M. F., Liu, H., Kenney, S., and Gottschalk, S. (2011). T cells redirected against CD70 for the immunotherapy of CD70-positive malignancies. Blood 117, 4304-4314.

Shah, A. J., Kapoor, N., Crooks, G. M., Weinberg, K. I., Azim, H. A., Killen, R., Kuo, L., Rushing, T., Kohn, D. B., and Parkman, R. (2007). The effects of Campath $1 \mathrm{H}$ upon graft-versushost disease, infection, relapse, and immune reconstitution in recipients of pediatric unrelated transplants. Biol. Blood Marrow Transplant. 13, 584-593.

Sharma, S. V., and Settleman, J. (2007). Oncogene addiction: setting the stage for molecularly targeted cancer therapy. Genes Dev. 21, 3214-3231.

Shochat, C., Tal, N., Bandapalli, O. R., Palmi, C., Ganmore, I., te Kronnie, G., Cario, G., Cazzaniga, G., Kulozik, A. E., Stanulla, M., Schrappe, M., Biondi, A., Basso, G., Bercovich, D., Muckenthaler, M. U., and Izraeli, S. (2011). Gain-of-function mutations in interleukin-7 receptor-alpha (IL7R) in childhood acute lymphoblastic leukemias. J. Exp. Med. 208, 901-908.

Siena, S., Sartore-Bianchi, A., Di Nicolantonio, F., Balfour, J., and Bardelli, A. (2009). Biomarkers predicting clinical outcome of epidermal growth factor receptor-targeted therapy in metastatic colorectal cancer. J. Natl. Cancer Inst. 101, 1308-1324.

Smith, M. R. (2003). Rituximab (monoclonal anti-CD20 antibody): mechanisms of action and resistance. Oncogene 22, 7359-7368.

Spanaki, A., Perdikogianni, C., Linardakis, E., and Kalmanti, M. (2007). Quantitative assessment of PRAME expression in diagnosis of childhood acute leukemia. Leuk. Res. 31, 639-642.

Spratlin, J. L., Cohen, R. B., Eadens, M., Gore, L., Camidge, D. R., Diab, S., Leong, S., O'Bryant, C., Chow, L. Q., Serkova, N. J., Meropol, N. J., Lewis, N. L., Chiorean, E. G., Fox, F., Youssoufian, H., Rowinsky, E. K., and Eckhardt, S. G. (2010). Phase I pharmacologic and biologic study of ramucirumab (IMC-1121B), a fully human immunoglobulin G1 monoclonal antibody targeting the vascular endothelial growth factor receptor-2. J. Clin. Oncol. 28, 780-787.

Stasi, R., Pagano, A., Stipa, E., and Amadori, S. (2001). Rituximab chimeric anti-CD20 monoclonal antibody treatment for adults with chronic idiopathic thrombocytopenic purpura. Blood 98 952-957.

Stein, H., Mason, D. Y., Gerdes, J., O'Connor, N., Wainscoat, J., Pallesen, G., Gatter, K., Falini, B., Delsol, G., and Lemke, H. (1985). The expression of the Hodgkin's disease associated antigen $\mathrm{Ki}-1$ in reactive and neoplastic lymphoid tissue: evidence that Reed-Sternberg cells and histiocytic malignancies are derived from activated lymphoid cells. Blood 66, 848-858.

Steinbach, D., Schramm, A., Eggert, A., Onda, M., Dawczynski, K., Rump, A., Pastan, I., Wittig, S., Pfaffendorf, N., Voigt, A., Zintl, F., and Gruhn, B. (2006). Identification of a set of seven genes for the monitoring of minimal residual disease in pediatric acute myeloid leukemia. Clin. Cancer Res. 12, 2434-2441.

Steinbach, D., Viehmann, S., Zintl, F., and Gruhn, B. (2002). PRAME gene expression in childhood acute lymphoblastic leukemia. Cancer Genet. Cytogenet. 138, 89-91.

Stone, M. J., Sausville, E. A., Fay, J. W., Headlee, D., Collins, R. H., Figg, W. D., Stetler-Stevenson, M., Jain, V., Jaffe, E. S., Solomon, D., Lush, R. M., Senderowicz, A., Ghetie, V., Schindler, J., Uhr, J. W., and Vitetta, E. S. (1996). A phase I study of bolus versus continuous infusion of the anti-CD19 immunotoxin, IgGHD37-dgA, in patients with B-cell lymphoma. Blood 88, 1188-1197.

Suzuki, H., Onishi, H., Wada, J. Yamasaki, A., Tanaka, H., Nakano, K. Morisaki, T., and Katano, M. (2010). VEGFR2 is selectively expressed by FOXP3high CD4+ Treg. Eur. J. Immunol. 40, 197-203.

Svennerholm, L., Bostrom, K., Fredman, P., Jungbjer, B., Lekman, A., Månsson, J. E., and Rynmark, B. M. (1994). Gangliosides and allied glycosphingolipids in human peripheral nerve and spinal cord. Biochim. Biophys. Acta 1214, 115-123.

Takenouchi, M., Hirai, S., Sakuragi, N., Yagita, H., Hamada, H., and Kato, K. (2011). Epigenetic modulation enhances the therapeutic effect of anti-IL-13R(alpha)2 antibody in human mesothelioma xenografts. Clin. Cancer Res. 17, 2819-2829.
Tang, S. C., Hewitt, K., Reis, M. D., and Berinstein, N. L. (1996). Immunosuppressive toxicity of CAMPATH1H monoclonal antibody in the treatment of patients with recurrent low grade lymphoma. Leuk. Lymphoma 24, 93-101.

Taylor, J. G. VI., Cheuk, A. T., Tsang, P. S., Chung, J. Y., Song, Y. K., Desai, K., Yu, Y., Chen, Q. R., Shah, K., Youngblood, V., Fang, J., Kim, S. Y., Yeung, C., Helman, L. J., Mendoza, A., Ngo, V., Staudt, L. M., Wei, J. S., Khanna, C., Catchpoole, D., Qualman, S. J., Hewitt, S. M., Merlino, G., Chanock, S. J., and Khan, J. (2009). Identification of FGFR4-activating mutations in human rhabdomyosarcomas that promote metastasis in xenotransplanted models. J. Clin. Invest. 119, 3395-3407.

Thomas, D. A., Faderl, S., O’Brien, S., Bueso-Ramos, C., Cortes, J., GarciaManero, G., Giles, F. J., Verstovsek, S., Wierda, W. G., Pierce, S. A., Shan, J., Brandt, M., Hagemeister, F. B., Keating, M. J., Cabanillas, F., and Kantarjian, H. (2006) Chemoimmunotherapy with hyperCVAD plus rituximab for the treatment of adult Burkitt and Burkitttype lymphoma or acute lymphoblastic leukemia. Cancer 106, 1569-1580.

Thway, K., Selfe, J., Missiaglia, E., Fisher, C., and Shipley, J. (2011). Glypican-3 is expressed in rhabdomyosarcomas but not adult spindle cell and pleomorphic sarcomas. J. Clin. Pathol. 64, 587-591.

Till, B. G., Jensen, M. C., Wang, J., Chen, E. Y., Wood, B. L., Greisman, H. A., Qian, X., James, S. E., Raubitschek, A., Forman, S. J., Gopal, A. K., Pagel, J. M., Lindgren, C. G., Greenberg, P. D., Riddell, S. R., and Press, O. W. (2008). Adoptive immunotherapy for indolent non-Hodgkin lymphoma and mantle cell lymphoma using genetically modified autologous CD20-specific T cells. Blood 112, 2261-2271.

Toledo, S. R., Zago, M. A., Oliveira, I. D., Proto-Siqueira, R., Okamoto, O. K., Severino, P., Vêncio, R. Z., Gamba, F. T., Silva, W. A., MoreiraFilho, C. A., Torre, C. A., Alves, M. T., Garcia-Filho, R. J., Simpson, A. J., and Petrilli, A. S. (2011). Insights on PRAME and osteosarcoma by means of gene expression profiling. J. Orthop. Sci. 16, 458-466.

Tong, C. Y., Hui, A. B., Yin, X. L., Pang, J. C., Zhu, X. L., Poon, W. S., and Ng, H. K. (2004). Detection of oncogene amplifications in medulloblastomas by comparative genomic hybridization and array-based comparative 
genomic hybridization. J. Neurosurg. 100, 187-193.

Topp, M. S., Kufer, P., Gokbuget, N., Goebeler, M., Klinger, M., Neumann, S., Horst, H. A., Raff, T., Viardot, A., Schmid, M., Stelljes, M., Schaich, M., Degenhard, E., Köhne-Volland, R., Brüggemann, M., Ottmann, O., Pfeifer, H., Burmeister, T., Nagorsen, D., Schmidt, M., Lutterbuese, R., Reinhardt, C., Baeuerle, P. A., Kneba, M., Einsele, H., Riethmüller, G., Hoelzer, D., Zugmaier, G., and Bargou, R. C. (2011). Targeted therapy with the T-cellengaging antibody blinatumomab of chemotherapy-refractory minimal residual disease in B-lineage acute lymphoblastic leukemia patients results in high response rate and prolonged leukemia-free survival. J. Clin. Oncol. 29, 2493-2498.

Turk, M. J., Wolchok, J. D., GuevaraPatino, J. A., Goldberg, S. M., and Houghton, A. N. (2002). Multiple pathways to tumor immunity and concomitant autoimmunity. Immunol. Rev. 188, 122-135.

Urba, W. J., and Longo, D. L. (2011). Redirecting T cells. N. Engl. J. Med. 365, 754-757.

Vallera, D. A., Chen, H., Sicheneder, A. R., Panoskaltsis-Mortari, A., and Taras, E. P. (2009). Genetic alteration of a bispecific ligand-directed toxin targeting human CD19 and CD22 receptors resulting in improved efficacy against systemic B cell malignancy. Leuk. Res. 33, 1233-1242.

van den Broeke, L. T., Pendleton, C. D., Mackall, C., Helman, L. J., and Berzofsky, J. A. (2006). Identification and epitope enhancement of a PAXFKHR fusion protein breakpoint epitope in alveolar rhabdomyosarcoma cells created by a tumorigenic chromosomal translocation inducing CTL capable of lysing human tumors. Cancer Res. 66, 1818-1823.

Vulcani-Freitas, T. M., Saba-Silva, N., Cappellano, A., Cavalheiro, S., and Toledo, S. R. (2011). PRAME gene expression profile in medulloblastoma. Arq. Neuropsiquiatr. 69, 9-12.

Wayne, A., Bhojwani, D., Silverman, L. B., Richards, K., Stetler-Stevenson, M., Shah, N. N., Jeha, S., Pui, C., Buzoianu, M., FitzGerald, D. J., Kreitman, R. J., Ibrahim, R., and Pastan, I. (2011). "A novel anti-CD22 immunotoxin, moxetumomab pasudotox: phase I study in pediatric acute lymphoblastic leukemia (ALL)," in ASH Annual Meeting Abstracts, San Diego, CA, 248.

Webb, T. R., Slavish, J., George, R. E., Look, A. T., Xue, L., Jiang, Q., Cui, X., Rentrop, W. B., and Morris, S. W. (2009). Anaplastic lymphoma kinase: role in cancer pathogenesis and small-molecule inhibitor development for therapy. Expert Rev. Anticancer Ther. 9, 331-356.

Weinstein, I. B., and Joe, A. (2008). Oncogene addiction. Cancer Res. 68, 3077-3080; discussion 80 .

Wellstein, A., and Toretsky, J. A. (2011). Hunting ALK to feed targeted cancer therapy. Nat. Med. 17, 290-291.

Wesche, J., Haglund, K., and Haugsten, E. M. (2011). Fibroblast growth factors and their receptors in cancer. Biochem. J. 437, 199-213.

Williamson, D., Selfe, J., Gordon, T., Lu, Y. J., Pritchard-Jones, K., Murai, K., Jones, P., Workman, P., and Shipley, J. (2007). Role for amplification and expression of glypican-5 in rhabdomyosarcoma. Cancer Res. 67, 57-65.

Wischhusen, J., Jung, G., Radovanovic, I., Beier, C., Steinbach, J. P., Rimner, A., Huang, H., Schulz, J. B., Ohgaki, H., Aguzzi, A., Rammensee, H. G., and Weller, M. (2002). Identification of CD70-mediated apoptosis of immune effector cells as a novel immune escape pathway of human glioblastoma. Cancer Res. 62, 2592-2599.

Witzig, T. E., Fishkin, P., Gordon, L. I., Gregory, S. A., Jacobs, S., Macklis, R., McLaughlin, P., Press, O., and Zelenetz, A. D. (2011). Treatment recommendations for radioimmunotherapy in follicular lymphoma: a consensus conference report. Leuk. Lymphoma 52, 1188-1199.

Worley, B. S., van den Broeke, L. T., Goletz, T. J., Pendleton, C. D., Daschbach, E. M., Thomas, E. K., Marincola, F. M., Helman, L. J., and Berzofsky, J. A. (2001). Antigenicity of fusion proteins from sarcoma-associated chromosomal translocations. Cancer Res. 61, 6868-6875.

Wortzel, R. D., Philipps, C., and Schreiber, H. (1983). Multiple tumour-specific antigens expressed on a single tumour cell. Nature 304, 165-167.
Woyach, J. A., Ruppert, A. S., Heerema, N. A., Peterson, B. L., Gribben, J. G., Morrison, V. A., Rai, K. R., Larson, R. A., and Byrd, J. C. (2011). Chemoimmunotherapy with fludarabine and rituximab produces extended overall survival and progression-free survival in chronic lymphocytic leukemia: long-term follow-up of CALGB study 9712. J. Clin. Oncol. 29, 1349-1355.

Wynn, T. A. (2003). IL-13 effector functions. Annu. Rev. Immunol. 21, 425-456.

Xu, H., Cheung, I. Y., Guo, H. F., and Cheung, N. K. (2009). MicroRNA miR-29 modulates expression of immunoinhibitory molecule B7-H3: potential implications for immune based therapy of human solid tumors. Cancer Res. 69, 6275-6281.

Yotnda, P., Firat, H., Garcia-Pons, F., Garcia, Z., Gourru, G., Vernant, J. P., Lemonnier, F. A., Leblond, V., and Langlade-Demoyen, P. (1998a). Cytotoxic $\mathrm{T}$ cell response against the chimeric $\mathrm{p} 210 \mathrm{BCR}-\mathrm{ABL}$ protein in patients with chronic myelogenous leukemia. J. Clin. Invest. 101, 2290-2296.

Yotnda, P., Garcia, F., Peuchmaur, M. Grandchamp, B., Duval, M., Lemonnier, F., Vilmer, E., and LangladeDemoyen, P. (1998b). Cytotoxic T cell response against the chimeric ETV6-AML1 protein in childhood acute lymphoblastic leukemia. J. Clin. Invest. 102, 455-462.

Younes, A., Bartlett, N. L., Leonard, J. P., Kennedy, D. A., Lynch, C. M., Sievers, E. L., and Forero-Torres, A. (2010). Brentuximab vedotin (SGN35) for relapsed CD30-positive lymphomas. N. Engl. J. Med. 363, 1812-1821.

Yu, A. L., Gilman, A. L., Ozkaynak, M. F., London, W. B., Kreissman, S. G., Chen, H. X., Smith, M., Anderson, B., Villablanca, J. G., Matthay, K. K., Shimada, H., Grupp, S. A., Seeger, R., Reynolds, C. P., Buxton, A., Reisfeld, R. A., Gillies, S. D., Cohn, S. L., Maris, J. M., Sondel, P. M., and Children's Oncology Group. (2010). Anti-GD2 antibody with GM-CSF, interleukin-2, and isotretinoin for neuroblastoma. N. Engl. J. Med. 363, 1324-1334.

Zendman, A. J., Van Kraats, A. A., Weidle, U. H., Ruiter, D. J., and Van Muijen, G. N. (2002). The XAGE family of cancer/testis-associated genes: alignment and expression profile in normal tissues, melanoma lesions and Ewing's sarcoma. Int. J. Cancer 99, 361-369.

Zhang, G. B., Zhou, H., Chen, Y. J., Ge, Y., Xie, F., Shi, Q., Ma, H. B., Fei, M., and Zhang, X. G. (2005). Characterization and application of two novel monoclonal antibodies against 2IgB7-H3: expression analysis of 2IgB7-H3 on dendritic cells and tumor cells. Tissue Antigens 66, 83-92.

Zhao, Y., Wang, Q. J., Yang, S., Kochenderfer, J. N., Zheng, Z., Zhong, X., Sadelain, M., Eshhar, Z., Rosenberg, S. A., and Morgan, R. A. (2009). A herceptin-based chimeric antigen receptor with modified signaling domains leads to enhanced survival of transduced $\mathrm{T}$ lymphocytes and antitumor activity. J. Immunol. 183, 5563-5574.

Zinzani, P. L., d'Amore, F., Bombardieri, E., Brammer, C., Codina, J. G., Illidge, T., Jurczak, W., Linkesch, W., Morschhauser, F., Vandenberghe, E., and Van Hoof, A. (2008). Consensus conference: implementing treatment recommendations on Yttrium-90 immunotherapy in clinical practice - report of a European workshop. Eur. J. Cancer 44, 366-373.

Conflict of Interest Statement: The authors declare that the research was conducted in the absence of any commercial or financial relationships that could be construed as a potential conflict of interest.

Received: 29 September 2011; paper pending published: 12 October 2011; accepted: 04 January 2012; published online: 30 January 2012.

Citation: Orentas RJ, Lee DW and Mackall $C$ (2012) Immunotherapy targets in pediatric cancer. Front. Oncol. 2:3. doi: 10.3389/fonc. 2012.00003

This article was submitted to Frontiers in Pediatric Oncology, a specialty of Frontiers in Oncology.

Copyright (C) 2012 Orentas, Lee and Mackall. This is an open-access article distributed under the terms of the Creative Commons Attribution Non Commercial License, which permits noncommercial use, distribution, and reproduction in other forums, provided the original authors and source are credited. 